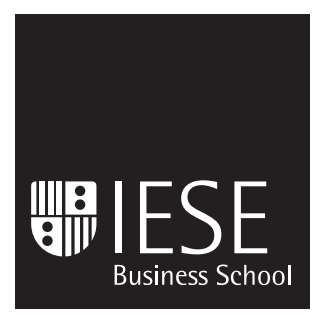

CIIF

Working Paper

WP-746

University of Navarra

\title{
POOR PERFORMANCE OF MUTUAL FUNDS IN SPAIN 1991-2007
}

\author{
Pablo Fernández \\ Vicente J. Bermejo \\ Andrada Bilan
}


The CIIF, International Center for Financial Research, is an interdisciplinary center with an international outlook and a focus on teaching and research in finance. It was created at the beginning of 1992 to channel the financial research interests of a multidisciplinary group of professors at IESE Business School and has established itself as a nucleus of study within the School's activities.

Ten years on, our chief objectives remain the same:

- Find answers to the questions that confront the owners and managers of finance companies and the financial directors of all kinds of companies in the performance of their duties

- Develop new tools for financial management

- Study in depth the changes that occur in the market and their effects on the financial dimension of business activity

All of these activities are programmed and carried out with the support of our sponsoring companies. Apart from providing vital financial assistance, our sponsors also help to define the Center's research projects, ensuring their practical relevance.

The companies in question, to which we reiterate our thanks, are:

Aena, A.T. Kearney, Caja Madrid, Fundación Ramón Areces, Grupo Endesa, Royal Bank of Scotland and Unión Fenosa.

http://www.iese.edu/ciif/ 


\title{
POOR PERFORMANCE OF MUTUAL FUNDS IN SPAIN 1991-2007
}

\author{
Pablo Fernández ${ }^{1}$ \\ Vicente J. Bermejo ${ }^{2}$ \\ Andrada Bilan ${ }^{2}$
}

\begin{abstract}
During the past 10 to 16 years, the average return on mutual funds in Spain was lower than the average return on government bonds at any term. During the past 10 years, the average return on the funds was lower than inflation. In spite of these results, on December 31, 2007, 8,264,240 investors held 238.7 billion Euros in the 2,907 existing mutual funds. During 2007, the number of shareholders descended by 555,569 and the value of their assets dropped by $6.1 \%$.

Only 30 of the 935 mutual funds with 10-year history outperformed the benchmark, and only two of them outperformed the overall index of the Madrid Stock Exchange (ITBM).

If the return of every mutual fund in the past 16 years had not been the one obtained but instead the benchmark of its category, the appreciation of the funds over 1992-2007 would have been $€ 180$ billion, instead of the $€ 80$ billion they achieved. The total of fees and other expenses for the period ascended to $€ 34$ billion.
\end{abstract}

\footnotetext{
${ }^{1}$ Professor of Financial Management, PricewaterhouseCoopers Chair of Finance, IESE

${ }^{2}$ Research Assistant, IESE
}

Classification JEL: G12, G31, M21

Keywords: Mutual funds, CBMV, INVERCO, return to shareholders, benchmark, appreciation of the funds, TER. 


\section{POOR PERFORMANCE OF MUTUAL FUNDS IN SPAIN 1991-2007}

We analyze the return on Spanish mutual funds over the 1991-2007 period.

Table 1 shows the main characteristics of mutual funds in Spain. As of December 31 2007, 8,264,240 investors held $€ 228,299$ million in the 2,907 existing mutual funds. During 2007, the number of shareholders descended by 555,569 and the value of their assets dropped by $6.1 \%$.

What is surprising is the large number of existing funds and their spread.

\section{Table 1}

Main Characteristics of Spanish Mutual Funds, 1991-2007

\begin{tabular}{|c|c|c|c|c|c|c|c|c|c|c|c|c|c|c|c|c|c|}
\hline & 1991 & 1992 & 1993 & 1994 & 1995 & 1996 & 1997 & 1998 & 1999 & 2000 & 2001 & 2002 & 2003 & 2004 & 2005 & 2006 & 2007 \\
\hline Value of assets ( $€$ billion) & 23.2 & 37.8 & 61.6 & 67.6 & 73.3 & 112 & 162 & 204 & 206 & 183 & 180 & 171 & 198 & 220 & 246 & 254 & 239 \\
\hline Number of funds & 374 & 480 & 579 & 663 & 752 & 959 & 1.458 & 1.867 & 2.154 & 2.426 & 2.540 & 2.487 & 2.623 & 2.654 & 2.616 & 2.779 & 2.907 \\
\hline Shareholders (millions) & 1.15 & 1.68 & 2.55 & 2.79 & 2.94 & 4.29 & 6.24 & 7.98 & 8.01 & 7.66 & 7.45 & 7.13 & 7.63 & 8.04 & 8.56 & 8.82 & 8.26 \\
\hline Holdings/fund ( $€$ millions) & 62 & 79 & 106 & 102 & 97 & 117 & 111 & 109 & 95 & 76 & 71 & 69 & 75 & 83 & 94 & 92 & 82 \\
\hline Holdings/holder ( $€$ thousands) & 20 & 23 & 24 & 24 & 25 & 26 & 26 & 26 & 26 & 24 & 24 & 24 & 26 & 27 & 29 & 29 & 29 \\
\hline
\end{tabular}

In Table 2, we compare the average return on mutual funds in Spain during the past 3, 5, 10 and 16 years $(4.03 \% ; 3.81 \% ; 2.22 \% ; 4.54 \%)$ with inflation, stock market investment and Spanish government bonds. It is surprising that, over the past 10 years, mutual funds did not achieve sufficient results to cover the loss of value due to inflation. In fact, average return on the funds over the last 10 and 16 years was below that of state bonds at any term.

Note: The authors are thankful for the observations made on previous editions of this paper by Manuel Andrade, León Bartolomé, Juan Palacios and Ignacio Pedrosa. 


\section{Table 2}

Comparison of Return on Spanish Mutual Funds and Other Magnitudes

\begin{tabular}{|l|r|r|r|r|}
\cline { 2 - 5 } \multicolumn{1}{c|}{} & \multicolumn{4}{|c|}{$\begin{array}{c}\text { Annual average return of the period } \\
\text { ending in December of } 2007\end{array}$} \\
\cline { 2 - 5 } \multicolumn{1}{c|}{} & $\mathbf{3}$ Years & $\mathbf{5}$ Years & $\mathbf{1 0}$ Years & $\mathbf{1 6}$ Years \\
\hline Mutual funds (source: INVERCO) & $\mathbf{4 . 0 3} \%$ & $\mathbf{3 . 8 1} \%$ & $\mathbf{2 . 2 2} \%$ & $\mathbf{4 . 5 4 \%}$ \\
\hline Inflation & $3.2 \%$ & $3.2 \%$ & $3.0 \%$ & $3.4 \%$ \\
\hline
\end{tabular}

\begin{tabular}{|c|c|c|c|c|}
\hline 1 day & $2.9 \%$ & $2.6 \%$ & $3.2 \%$ & $5.5 \%$ \\
\hline 1 year & $2.7 \%$ & $2.7 \%$ & $3.4 \%$ & $5.8 \%$ \\
\hline 3 years & $2.4 \%$ & $3.0 \%$ & $4.3 \%$ & $7.4 \%$ \\
\hline 10 years & $2.1 \%$ & $4.3 \%$ & $5.8 \%$ & $9.5 \%$ \\
\hline
\end{tabular}

\begin{tabular}{|c|c|c|c|c|}
\hline ITBM & $24.5 \%$ & $25.9 \%$ & $13.7 \%$ & $16.4 \%$ \\
\hline IBEX 35 (with dividends) & $22.5 \%$ & $24.1 \%$ & $10.4 \%$ & $15.1 \%$ \\
\hline IBEX 35 equally weighted ${ }^{*}$ & $22.2 \%$ & $25.7 \%$ & $13.1 \%$ & $16.4 \%$ \\
\hline Top 30 DIV weighted* & $27.0 \%$ & $26.3 \%$ & $20.5 \%$ & $22.6 \%$ \\
\hline Top 20 Book/P weighted* & $40.9 \%$ & $36.5 \%$ & $30.6 \%$ & $30.8 \%$ \\
\hline
\end{tabular}

Only four of the 935 funds with at least 10 years of history provided a higher return than 12\%: Bestinver stock market (18.9\%), Bestinfon (17.2\%), Bestinver Mixed (13.4\%) and Bestinver international (12.05\%). Significantly, all four of them belong to the same fund manager. twenty-six funds (seven of them guaranteed) with a 10-year history provided a negative return! The value of their assets was €803 million in December 2007.

Only five of the 238 funds with a 16-year history provided a higher return than 12\%: Fonbilbao shares (14.13\%), Citifondo R.V. (12.86\%), MS stock market (12.73\%), EDM-investment (12.49\%) and Metavalor (12.31\%).

Figure 1 shows the return on the 238 funds with a 16-year history, from the highest (14.13\%) to the lowest $(-1.23 \%)$. This chart allows us to make some observations:

- 166 of the 238 funds had a lower return than 1-day Spanish government bonds.

- 201 of the 238 funds had a lower return than 3-year Spanish government bonds.

- 218 of the 238 funds had a lower return than 10-year Spanish government bonds.

- All the 238 funds had a lower return than the IBEX35 or the overall index of the Madrid Stock Exchange. 


\section{Figure 1}

Return on the 238 Mutual Funds with a 16-year History

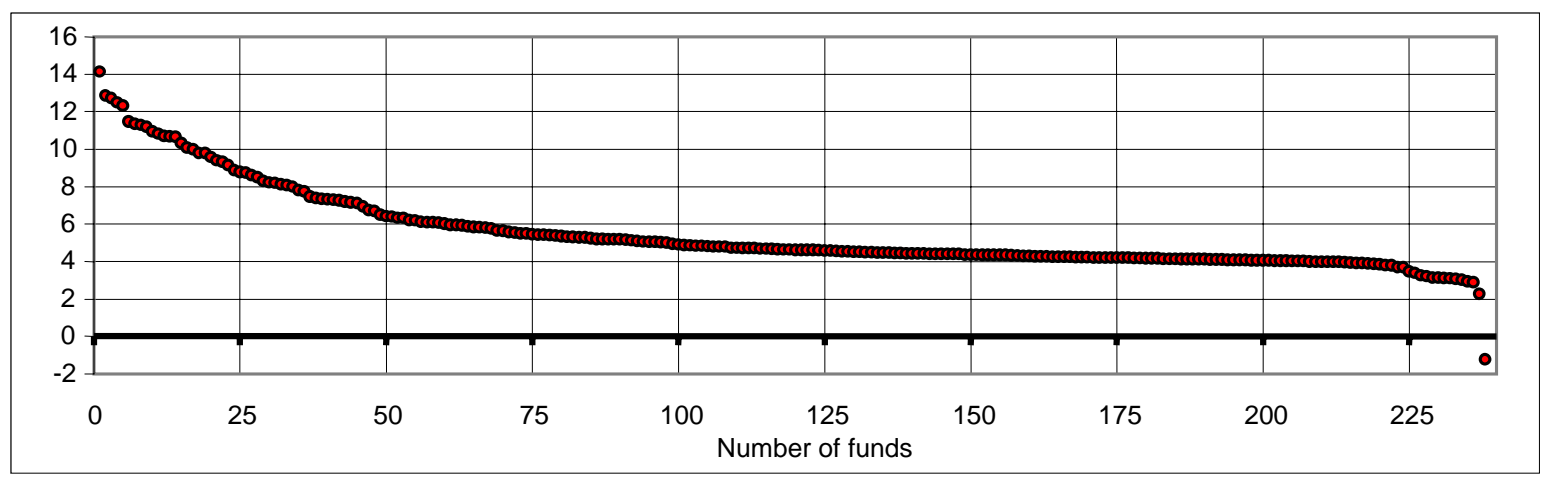

Source: Inverco

The information provided in Figure 2 is similar to the one in Figure 1 but it is expressed in Euros: it shows how much 1 Euro invested in December 1991 in each of the funds was worth by December 2007. 1 Euro became €8.29 in the case of the most profitable fund and €0.82 in the least profitable.

\section{Figure 2}

Return in Euros on the 238 Mutual Funds with a 16-year History

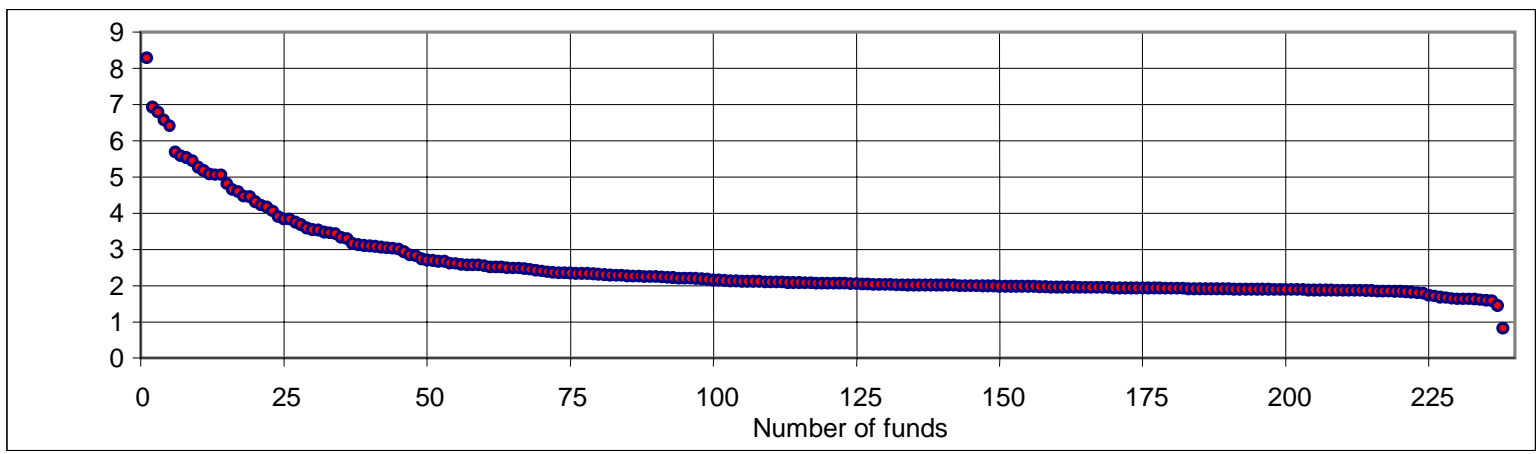

Source: Inverco

Figure 3 shows the return on the 935 funds with a 10-year history, from the highest (18.9\%) to the lowest $(-15.1 \%)$. This chart allows us to make some observations:

- 557 of the 935 funds had a lower return than inflation.

- 593 of the 935 funds had a lower return than 1-day Spanish government bonds.

- 736 of the 935 funds had a lower return than 3-year Spanish government bonds.

- 820 of the 935 funds had a lower return than 10-year Spanish government bonds.

- Only two of the 935 funds had a higher return than the overall index of the Madrid Stock Exchange. 


\section{Figure 3}

Return on the 935 Mutual Funds with a 10-year History

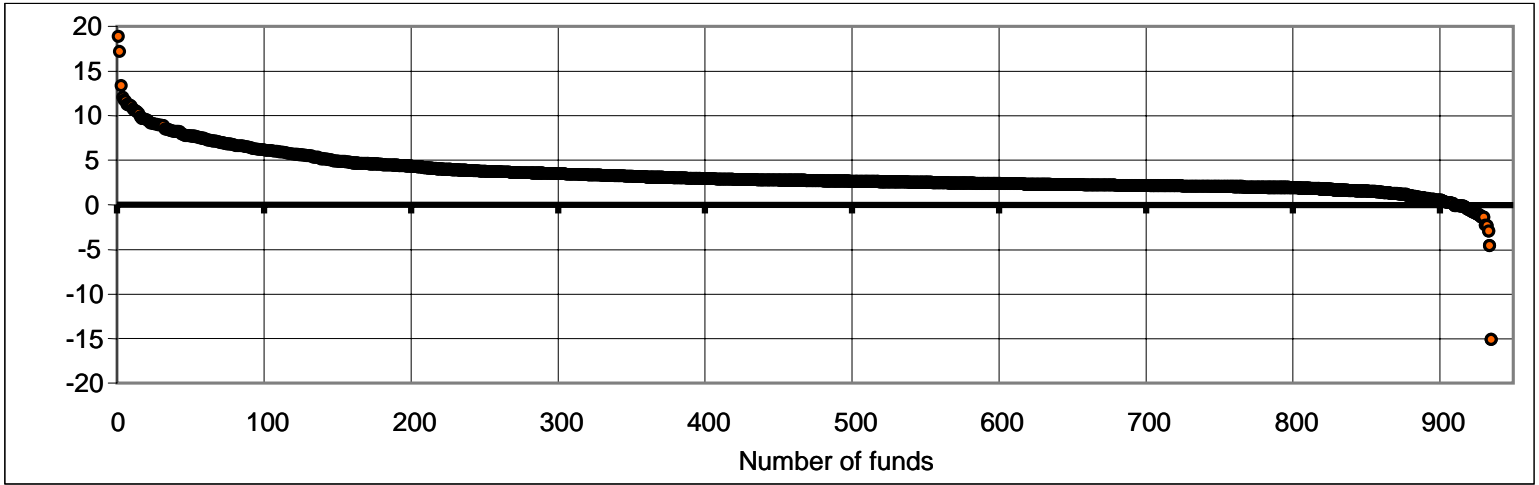

Source: Inverco.

The information provided in Figure 4 is similar to the one in Figure 3 but it is expressed in Euros: it shows how much 1 Euro invested in December 1997 in each of the 935 funds was worth by December 2007. One Euro became $€ 5.95$ in the case of the most profitable fund and $€ 0.19$ in the least profitable.

\section{Figure 4}

Return in Euros on the 935 Mutual Funds with a 10-year History

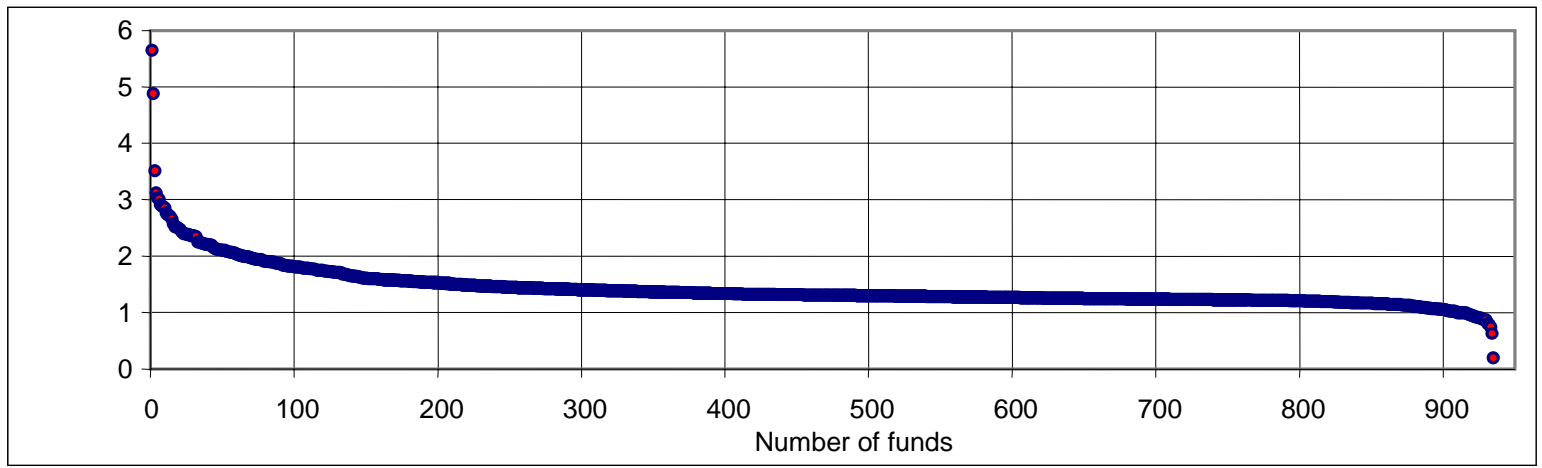

Source: Inverco

Figure 5 shows the return on the 2,663 funds that existed during 2007, from the highest $(40.3 \%)$ to the lowest $(-32.4 \%)$. This chart allows us to make the following observations:

- 2,105 of the 2,663 funds had a lower return than inflation.

- 519 of the funds had a negative return. 57 of them were guaranteed; 47 were international, fixed-income; 17 were long-term, fixed-income; 7 were mixed, fixedincome; and 34 were mixed equity. 


\section{Figure 5}

Return on the 2663 Mutual Funds with 1 - year (2007) History

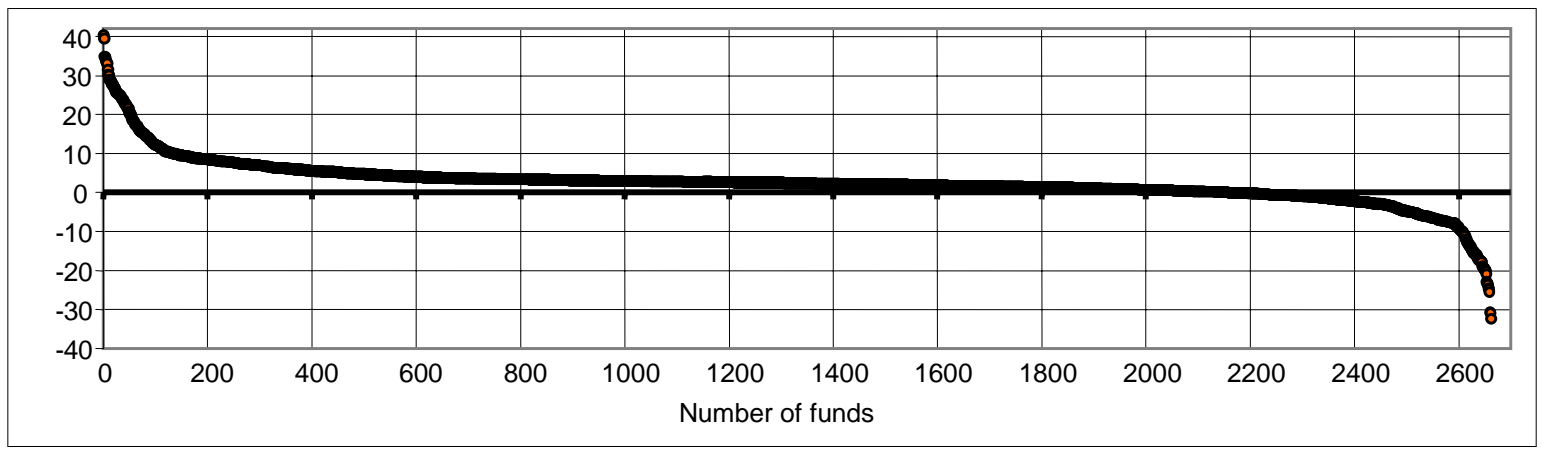

Source: Inverco

\section{Return Analysis on Each Category of Funds}

In this paper, mutual funds are grouped according to categories established by INVERCO (see Appendix 1). The return on the funds in each category is compared with a benchmark mentioned in Appendix 1. For example, the return on the funds falling into "National Equity Mutual Funds" category is compared to the return on the overall index of the Madrid Stock Exchange. Also, "Short-term, fixed-income" funds are up against the return of 1-day Repos.

Tables 3 and 4 sum-up this comparison. For example, the holdings of the funds belonging to the "National Equity Mutual Funds" category increased from $€ 123$ million at the end of 1991 , to $€ 7,825$ million at the end of 2007 . The weighted return of these funds during the last three years $(2005,2006$, and 2007) was 19.5\%, and during the last 16 years (from December 1991 until December 2007) was 11.5\%. The annual average return of ITBM during the three years was $24.5 \%$ (5\% more than the average of the funds), and during the last 10 years it amounted to $13.7 \%$ (5.6 more than the average of the funds).

According to Table 4, from the 122 National Equity Mutual Funds that existed at the end of 2007, only 16 were created more than 16 years ago, 61 of them had 10 years of history, 90 had five years and 104 had three years. None of the 16 funds with a minimum of 16 years of history had a higher return than the benchmark. None of the 61 funds with a minimum of 10 years of history had a higher return than the benchmark. Only two of the 99 National equity mutual funds with a minimum of five years of history had a higher return than the benchmark. ${ }^{1}$

\footnotetext{
${ }^{1}$ A paper analyzing the return on Spanish equity mutual funds can be downloaded from: http://ssrn.com/abstract=985120
} 


\section{Table 3}

Historical Return on Mutual Funds to Shareholders and Difference with the Benchmark

\begin{tabular}{|c|c|c|c|c|c|c|c|c|c|c|c|}
\hline & & \multicolumn{2}{|c|}{$\begin{array}{c}\text { Holding } \\
\text { billions of } €\end{array}$} & \multicolumn{4}{|c|}{$\begin{array}{c}\text { Historical return to shareholders (\%) } \\
\text { until } 2007 \\
\end{array}$} & \multicolumn{4}{|c|}{$\begin{array}{l}\text { Return differential (\%) } \\
\text { Historical - Benchmark }\end{array}$} \\
\hline & & 1991 & 2007 & 3 Years & 5 Years & 10 Years & 16 Years & $\begin{array}{l}3 \\
\text { Years }\end{array}$ & $\begin{array}{c}5 \\
\text { Years }\end{array}$ & $\begin{array}{c}10 \\
\text { Years }\end{array}$ & $\begin{array}{l}16 \\
\text { Years }\end{array}$ \\
\hline \multirow{3}{*}{$\begin{array}{l}\text { Fixed } \\
\text { Income }\end{array}$} & Short-term & 15.53 & 92.3 & 2.15 & 2.0 & 2.43 & 4.40 & -0.7 & -0.6 & -0.8 & -1.1 \\
\hline & Long-term & 4.85 & 6.4 & 1.2 & 1.8 & 2.63 & 4.78 & -1.1 & -1.8 & -2.4 & -3.7 \\
\hline & Mixed & 1.30 & 8.3 & 4.0 & 4.2 & 2.73 & 5.17 & -4.0 & -5.1 & -4.9 & -5.7 \\
\hline \multirow{2}{*}{ Equity } & Mixed & 0.42 & 6.3 & 9.2 & 9.2 & 3.77 & 6.54 & $\begin{array}{l}-8.8 \\
\end{array}$ & -10.1 & -7.8 & -7.9 \\
\hline & National & 0.12 & 7.8 & 19.5 & 21.2 & 8.11 & 11.49 & -5.0 & -4.7 & -5.6 & -4.9 \\
\hline \multirow{10}{*}{ Internat. } & Fixed income & 0.26 & 0.9 & 0.5 & 1.0 & 2.22 & 4.84 & -2.7 & 2.4 & -1.2 & -3.5 \\
\hline & F. income Mixed & 0.47 & 4.7 & 3.0 & 2.7 & 2.25 & 4.60 & -2.8 & 0.2 & -2.8 & -5.1 \\
\hline & Equity Mixed & 0.05 & 2.7 & 5.8 & 5.8 & 1.79 & 5.56 & -4.6 & -3.3 & -4.8 & -5.7 \\
\hline & Variable Euro & 0.10 & 7.7 & 13.8 & 13.2 & 4.25 & 8.84 & -9.1 & -10.5 & -8.5 & -7.3 \\
\hline & Variable Europe & 0.01 & 5.7 & 12.6 & 11.8 & 3.40 & 7.21 & -1.2 & -1.2 & -2.5 & -5.5 \\
\hline & Variable USA & 0.01 & 0.8 & 4.3 & 4.2 & 0.47 & & -1.1 & -1.0 & -2.2 & \\
\hline & Variable Japan & 0.00 & 0.4 & 3.1 & 5.4 & & & -6.6 & -5.1 & & \\
\hline & Variable Emerging & 0.01 & 2.1 & 32.0 & 28.1 & 9.02 & 9.40 & 0.7 & 0.0 & -1.9 & -3.7 \\
\hline & Variable Rest & 0.01 & 4.5 & 9.4 & 8.6 & 0.24 & 4.85 & -7.6 & -7.7 & -7.8 & -7.5 \\
\hline & Global & 0.09 & 27.7 & 3.7 & 3.6 & 1.88 & 5.07 & -13.3 & -12.7 & -6.2 & -7.3 \\
\hline \multirow{3}{*}{ Guaranteed } & Fixed income & & 18.1 & 1.8 & 2.1 & 2.93 & & -0.7 & -0.8 & -1.0 & \\
\hline & Equity & & 42.2 & 3.6 & 3.6 & 3.93 & & -5.1 & -5.6 & -2.1 & \\
\hline & TOTAL of FUNDS & 23.2 & 238.7 & 4.03 & 3.81 & 2.22 & 4.54 & -3.2 & -2.7 & -2.2 & -2.2 \\
\hline
\end{tabular}

Weighted return (IRR) of all mutual funds from the year indicated until 2007

\begin{tabular}{|l|l|l|l|l|l|l|l|l|l|l|l|l|l|l|l|l|}
\hline 1990 & 1991 & 1992 & 1993 & 1994 & 1995 & 1996 & 1997 & 1998 & 1999 & 2000 & 2001 & 2002 & 2003 & 2004 & 2005 & 2006 \\
\hline $3.5 \%$ & $3.5 \%$ & $3.4 \%$ & $3.1 \%$ & $3.1 \%$ & $2.9 \%$ & $2.6 \%$ & $2.3 \%$ & $1.8 \%$ & $\mathbf{1 . 4 \%}$ & $2.0 \%$ & $2.6 \%$ & $3.8 \%$ & $3.8 \%$ & $\mathbf{4 . 0} \%$ & $3.7 \%$ & $2.4 \%$ \\
\hline
\end{tabular}

\section{Table 4}

Number of Funds for each Period and Number of Funds with a Higher Return than the Benchmark

\begin{tabular}{|c|c|c|c|c|c|c|c|c|c|c|}
\hline & \multirow{2}{*}{$\begin{array}{l}\text { Number } \\
\text { Funds } \\
\text { Dec. } \\
2007\end{array}$} & \multicolumn{4}{|c|}{$\begin{array}{l}\text { Number of funds for the period } \\
\text { until } 2007\end{array}$} & \multicolumn{4}{|c|}{$\begin{array}{l}\text { Number of funds with historical } \\
\text { return higher than the }\end{array}$} \\
\hline & & & $\begin{array}{l}3 \\
\text { Years }\end{array}$ & $\begin{array}{c}5 \\
\text { Years }\end{array}$ & $\begin{array}{c}10 \\
\text { Years }\end{array}$ & $\begin{array}{c}16 \\
\text { Years }\end{array}$ & $\begin{array}{c}3 \\
\text { Years }\end{array}$ & $\begin{array}{c}5 \\
\text { Years }\end{array}$ & $\begin{array}{c}10 \\
\text { Years }\end{array}$ & $\begin{array}{c}16 \\
\text { Years }\end{array}$ \\
\hline \multirow{3}{*}{$\begin{array}{l}\text { Fixed } \\
\text { Income }\end{array}$} & Short-term & 386 & 330 & 280 & $\overline{216}$ & 87 & 2 & 7 & 2 & $\overline{1}$ \\
\hline & Long-term & 144 & 128 & 115 & 90 & 32 & 11 & 7 & 0 & 0 \\
\hline & Mixed & 136 & 129 & 121 & 80 & 28 & 6 & 2 & 0 & 0 \\
\hline \multirow[t]{2}{*}{ Equity } & Mixed & 144 & 138 & 127 & 87 & 28 & $\begin{array}{l}\mathbf{0} \\
\end{array}$ & $\begin{array}{l}\mathbf{0} \\
\end{array}$ & 1 & $\mathbf{0}$ \\
\hline & National & 122 & 104 & 90 & 61 & 16 & 1 & 2 & 0 & 0 \\
\hline \multirow{10}{*}{ Internat. } & Fixed income & 65 & 51 & 44 & 24 & 8 & 2 & 30 & 2 & $\mathbf{0}$ \\
\hline & F. income Mixed & 76 & 65 & 55 & 16 & 6 & 7 & 40 & 0 & 0 \\
\hline & Equity Mixed & 79 & 70 & 68 & 24 & 6 & 4 & 6 & 0 & 0 \\
\hline & Variable Euro & 119 & 99 & 88 & 33 & 7 & 0 & 2 & 2 & 0 \\
\hline & Variable Europe & 71 & 54 & 47 & 14 & 2 & 16 & 17 & 2 & 0 \\
\hline & Variable USA & 43 & 38 & 32 & 5 & & 5 & 10 & 2 & \\
\hline & Variable Japan & 25 & 20 & 19 & & & 2 & 3 & & \\
\hline & Variable Emerging & 59 & 40 & 36 & 10 & 2 & 14 & 14 & 1 & 0 \\
\hline & Variable Rest & 159 & 137 & 128 & 24 & 2 & 9 & 7 & 1 & 0 \\
\hline & Globals & 423 & 246 & 169 & 75 & 14 & 7 & 5 & 2 & $\underline{0}$ \\
\hline \multirow[t]{3}{*}{ Guaranteed } & Fixed income & 262 & 145 & 100 & 65 & & 9 & 6 & 5 & \\
\hline & Equity & 594 & 386 & 289 & 111 & & 32 & 9 & 10 & \\
\hline & TOTAL of FUNDS & 2,907 & 2,180 & 1,808 & 935 & 238 & 127 & 167 & 30 & 1 \\
\hline
\end{tabular}


Table 5 reflects the volatility of the returns on funds falling into each category. For example, if we analyze the return on the 104 National Equity Mutual Funds with a 3-year existence, the fund with the highest average return reached $28.2 \%$ while the fund with the lowest average return reached only 7.5\%. The standard deviation of the 104 average returns ${ }^{2}$ was $3.1 \%$. The benchmark (the return of ITBM) reached a $24.5 \%$.

Figure 6 is a graphic representation of this dispersion and shows the maximum, minimum and average (weighted) returns on each category.

The dispersion of the returns on each category is dependent on the investment decisions of the fund managers, on fees and expenses, and on the investment philosophy of the fund. The latter refers to the fact that some categories include very different funds. For instance, the category "International, Variable Emerging" includes funds with such different names as "Bric, New Challenges," "Eastern Europe," "China," "Ibero America” and "Asia." The category "International, Equity Europe" includes funds such as small \& mid caps, active market, dividend, telecommunications, UK, Switzerland, real estate, quantitative, profit, solidarity dividend, euroindex, special situations and research.

\section{Table 5}

Average Return on Mutual Funds over the past Years

The table shows, for each category, the maximum and minimum returns, the standard deviations $(\sigma)$ of the returns and the benchmark

\begin{tabular}{|c|c|c|c|c|c|c|c|c|c|c|c|c|c|c|c|c|c|}
\hline & & \multicolumn{4}{|c|}{3 years } & \multicolumn{4}{|c|}{5 years } & \multicolumn{4}{|c|}{10 years } & \multicolumn{4}{|c|}{16 years } \\
\hline & & MAX & $\min$ & $\sigma$ & benc & MAX & $\min$ & $\sigma$ & benc & MAX & $\min$ & $\sigma$ & benc & MAX & $\min$ & $\sigma$ & benc \\
\hline \multirow{3}{*}{$\begin{array}{l}\text { Fixed } \\
\text { Income }\end{array}$} & Short-term & 5.43 & -0.32 & 0.5 & 2.89 & 3.2 & -1.6 & 0.5 & 2.6 & 3.4 & 0.4 & 0.4 & 3.2 & 5.8 & 3.1 & 0.4 & 5.5 \\
\hline & Long-term & 6.63 & -0.62 & 0.8 & 2.24 & 8.6 & 0.4 & 1.1 & 3.7 & 4.8 & 0.6 & 0.7 & 5.1 & 6.4 & 3.9 & 0.6 & 8.5 \\
\hline & Mixed & 11.96 & 1.06 & 1.7 & 7.95 & 13.2 & 1.0 & 1.7 & 9.3 & 6.0 & -1.0 & 1.1 & 7.6 & 7.3 & 3.7 & 0.8 & 10.8 \\
\hline \multirow{2}{*}{ Equity } & Mixed & 15.64 & 0.25 & 3.1 & 17.97 & 17.8 & 0.5 & 3.3 & 19.3 & 13.4 & -0.4 & 2.3 & 11.6 & 11.2 & 2.9 & 2.1 & 14.4 \\
\hline & National & 28.20 & 7.53 & 3.1 & 24.50 & 26.3 & 8.9 & 3.0 & 25.9 & 11.7 & 2.2 & 1.9 & 13.7 & 14.1 & 7.8 & 1.9 & 16.4 \\
\hline \multirow{10}{*}{ Internat. } & Fixed income & 3.62 & -2.85 & 1.4 & 3.19 & 6.8 & -6.2 & 3.5 & -1.3 & 4.7 & -0.1 & 1.3 & 3.5 & 5.3 & 3.1 & 0.9 & 8.4 \\
\hline & F. income Mixed & 6.88 & -0.34 & 1.6 & 5.84 & 7.7 & 0.5 & 1.5 & 2.5 & 3.5 & -1.1 & 1.2 & 5.0 & 6.2 & 2.3 & 1.5 & 9.7 \\
\hline & Equity Mixed & 28.33 & 0.21 & 4.5 & 10.42 & 27.5 & 0.8 & 4.4 & 9.1 & 4.6 & -0.9 & 1.6 & 6.6 & 8.0 & 3.1 & 1.6 & 11.2 \\
\hline & Variable Euro & 22.47 & -2.51 & 3.6 & 22.88 & 26.9 & 0.5 & 4.2 & 23.8 & 18.9 & 0.3 & 4.3 & 12.8 & 10.0 & 2.9 & 2.6 & 16.2 \\
\hline & Variable Europe & 25.25 & -2.76 & 4.2 & 13.82 & 27.8 & 6.1 & 4.6 & 13.0 & 7.1 & 1.5 & 1.8 & 5.9 & 11.4 & 9.4 & 1.4 & 12.7 \\
\hline & Variable USA & 6.56 & 0.02 & 1.7 & 5.35 & 14.0 & -0.3 & 3.7 & 5.2 & 3.7 & -4.6 & 3.7 & 2.7 & & & & \\
\hline & Variable Japan & 11.03 & -0.72 & 3.2 & 9.72 & 15.1 & 1.9 & 3.9 & 10.5 & & & & & & & & \\
\hline & Variable Emerging & 38.86 & 14.1 & 5.4 & 31.30 & 35.4 & 8.8 & 5.9 & 28.0 & 11.7 & 5.7 & 2.0 & 11.0 & 11.3 & 10. & 0.4 & 13.1 \\
\hline & Variable Rest & 30.26 & -5.51 & 5.5 & 16.98 & 26.8 & -2.8 & 4.9 & 16.3 & 12.1 & - & 4.6 & 8.0 & 7.3 & 3.9 & 2.4 & 12.4 \\
\hline & Globals & 25.08 & -3.81 & 4.9 & 16.98 & 23.3 & -1.9 & 4.8 & 16.3 & 9.5 & -2.9 & 2.2 & 8.0 & 10.3 & -1.2 & 2.7 & 12.4 \\
\hline \multirow{3}{*}{ Guaranteed } & Fixed income & 3.1 & -7.51 & 1.0 & 2.55 & 3.5 & -3.5 & 0.8 & 2.8 & 4.9 & -2.3 & 0.9 & 3.9 & & & & \\
\hline & Equity & 21.25 & -0.99 & 3.1 & 8.75 & 20.8 & -0.3 & 2.5 & 9.2 & 7.7 & -0.1 & 1.4 & 6.0 & & & & \\
\hline & TOTAL of FUNDS & 38.86 & -7.51 & & 7.7 & 35.4 & -6.2 & & 7.1 & 18.9 & 5 & & 5.2 & 14.1 & -1.2 & & 7.5 \\
\hline
\end{tabular}

\footnotetext{
2 The standard deviation of the average returns measures the dispersions of the resulted returns. If all the funds in a category had the same return, the standard deviation would be zero. The higher the standard deviation, the higher the dispersion of the returns. It can be observed that the categories with higher dispersion (volatility) were "Variable, Emerging”; "Variable, Rest”; "Variable, Euro," "Variable, Europe." The categories with the least dispersion (volatility) were "Short Term, Fixed Income" and "Long Term, Fixed Income."
} 


\section{Figure 6}

Mutual Funds Return in the past 3 and 10 Years

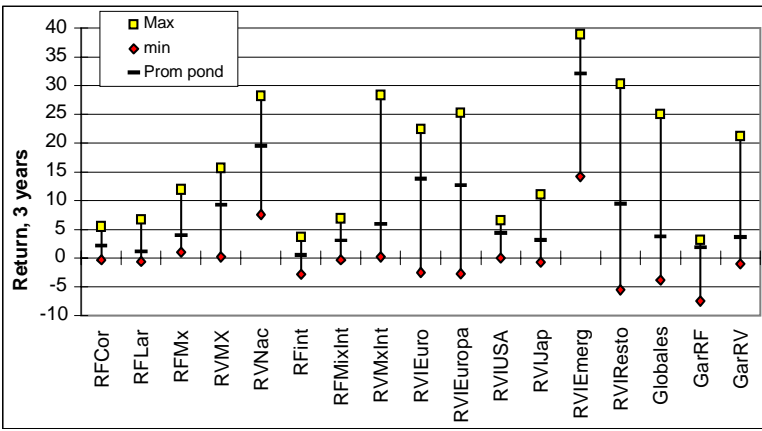

Average return, 3 years

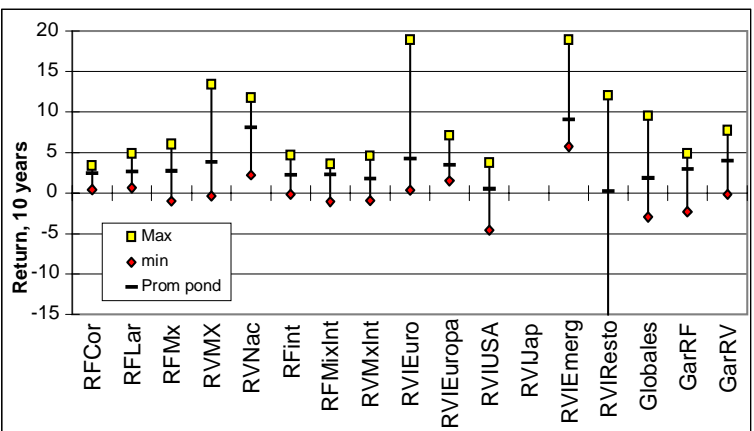

Average return, 10 years

\section{The Impact of the Return Differential from the Benchmark in the Capitalization and Appreciation of Mutual Funds}

If the return to shareholders of mutual funds had been similar to the benchmark, what would the value of their holdings be? This is the question we now address.

The first two columns in Table 6 reflect the equity of the funds in 1991 and 2007. The increase in the value of the total equity of the funds is due to the appreciation of the funds and to contributions (net investment) by investors over the years. Column 3 shows Net Investment (IN NET) of the shareholders, ${ }^{3}$ and Column 4 the appreciation of the funds between 1992 and 2007 (AP hist). It is obvious that:

$\mathrm{P} 2007=\mathrm{P} 1991+\mathrm{IN}$ NET + AP hist.

Column 5 reflects how much the funds would have had appreciated if their return had been the benchmark instead of the given return. Column 6 shows what the total equity of the funds would have been in 2007 if the appreciation was the one in Column 5, instead of the historical appreciation (Column 4) and if the Net Inversion of the shareholders had equaled the historical value (Column 3). Column 7 is the difference between Columns 4 and 5 (AP hist. - AP bench), and Column 8 is the percentage Column 7 represents in Column 4.

\footnotetext{
3 The table contains aggregated data obtained after calculations with annual data. We can use data published by Inverco in order to obtain the average return on each type of fund every year (Rt). Also, Inverso releases the value of the funds' holdings every year (Pt). Therefore, we can calculate the Net Investment of the shareholders using the following equation: IN NETt $=$ Pt - Pt-1 $(1+$ Rt). Net Investment is the difference between the contributions and withdrawals of the investors, assuming they were all realized on the last day of the year. Appendix 3 shows how to calculate Net Investment each year.
} 


\section{Table 6}

Value of Asset Holdings and Appreciation if the Return had been Equal to the benchmark, 1991-2006

Value of holdings 2007 = Value of holdings $1991+$ Net Investment 1992-07 + Appreciation. $\mathrm{P} 2007=\mathrm{P} 1991+\mathrm{IN}$ NET + AP

\begin{tabular}{|c|c|c|c|c|c|c|c|c|c|}
\hline \multirow{2}{*}{\multicolumn{2}{|c|}{ (data in million $€$ ) }} & \multirow{2}{*}{\multicolumn{2}{|c|}{$\begin{array}{l}\begin{array}{l}\text { Value of } \\
\text { holdings }\end{array} \\
\text { (millon } € \text { ) }\end{array}$}} & \multirow{2}{*}{\multicolumn{2}{|c|}{$\begin{array}{c}\text { History of the } \\
\text { Period 1992- } \\
2007 \\
\end{array}$}} & \multirow{2}{*}{\multicolumn{2}{|c|}{$\begin{array}{c}\text { If return = } \\
\text { benchmark }\end{array}$}} & \multirow{2}{*}{\multicolumn{2}{|c|}{$\begin{array}{c}\begin{array}{c}\text { Difference: history vs. } \\
\text { benchmark: }\end{array} \\
\text { AP hist - AP bench } \\
\end{array}$}} \\
\hline & & & & & & & & & \\
\hline & & P2007 & P1991 & IN NET & $\begin{array}{l}\text { AP } \\
\text { hist }\end{array}$ & $\begin{array}{c}\text { AP } \\
\text { bench }\end{array}$ & $\begin{array}{l}\text { P } 2007 \\
\text { bench }\end{array}$ & millon $€$ & \% \\
\hline & & {$[1]$} & [2] & [3] & [4] & [5] & {$[6]$} & {$[7]=[4]-[5]$} & {$[8]=[7] /[4]$} \\
\hline \multirow{3}{*}{$\begin{array}{l}\text { Fixed } \\
\text { Income }\end{array}$} & Short-term & 92.254 & 15.529 & 41.635 & 35.089 & 49.071 & 106.236 & -13.982 & $-40 \%$ \\
\hline & Long-term & 6.390 & 4.853 & -7.817 & 9.353 & 21.826 & 18.863 & -12.473 & $-133 \%$ \\
\hline & Mixed & 8.284 & 1.296 & 2.977 & 4.012 & 12.508 & 16.780 & -8.496 & $-212 \%$ \\
\hline \multirow{2}{*}{ Equity } & Mixed & 6.349 & 422 & 2.496 & 3.431 & 17.085 & 20.003 & -13.654 & $-398 \%$ \\
\hline & National & 7.825 & 123 & 396 & 7.306 & 15.371 & 15.891 & -8.066 & $-110 \%$ \\
\hline \multirow{10}{*}{ Internat. } & Fixed income & 903 & 256 & -145 & 792 & 1.677 & 1.789 & -886 & $-112 \%$ \\
\hline & F. income Mixed & 4.733 & 470 & 2.662 & 1.600 & 6.364 & 9.497 & -4.764 & $-298 \%$ \\
\hline & Equity Mixed & 2.708 & 53 & 2.375 & 280 & 2.555 & 4.983 & -2.275 & $-813 \%$ \\
\hline & Variable Euro & 7.717 & 102 & 5.994 & 1.621 & 9.646 & 15.742 & -8.025 & $-495 \%$ \\
\hline & Variable Europe & 5.703 & 14 & 4.588 & 1.101 & 1.989 & 6.591 & -888 & $-81 \%$ \\
\hline & Variable USA & 805 & 5 & 1.151 & -352 & -171 & 986 & -181 & $51 \%$ \\
\hline & Variable Japan & 443 & 1 & 1.086 & -645 & -540 & 547 & -104 & $16 \%$ \\
\hline & Variable Emerging & 2.111 & 7 & 1.139 & 966 & 1.142 & 2.287 & -176 & $-18 \%$ \\
\hline & Variable Rest & 4.462 & 11 & 7.344 & -2.893 & 3.306 & 10.661 & -6.199 & $214 \%$ \\
\hline & Globals & 27.707 & 90 & 25.219 & 2.397 & 11.226 & 36.536 & -8.828 & $-368 \%$ \\
\hline \multirow{3}{*}{ Guaranteed } & Fixed income & 18.110 & 0 & 13.028 & 5.082 & 6.620 & 19.648 & -1.538 & $-30 \%$ \\
\hline & Equity & 42.192 & 0 & 31.151 & 11.040 & 20.353 & 51.504 & -9.312 & $-84 \%$ \\
\hline & TOTAL of FUNDS & 238.699 & 23.234 & 135.282 & 80.184 & 180.027 & 338.542 & -99.843 & $-125 \%$ \\
\hline
\end{tabular}

The total equity of the funds went from 23.234 billion Euros in 1991 to 238.699 billion Euros in 2007. The reasons for the increase are the contributions by investors totaling 135.282 billion Euros, and the appreciation (yield) of the funds during 1992-2007 ( $€ 80.184$ billion). If the return on the funds had been equal to the benchmark for each category, the appreciation of the funds during 1992-2007 would have been $€ 180.027$ billion; that is, €100 billion more than the actual gains registered (125\% more than the appreciation of the funds). Consequently, we can conclude that, from the $€ 180.027$ billion mutual funds that could have appreciated following the benchmarks we employed, the shareholders only got $€ 80.184$ billion. Using the poor historical information offered by CNMV on fees charged by mutual funds, we can calculate the total of fees and charges (explicit commissions) in 1992-2006 at €34 billion. The other €66 billion (100-34) is due to hidden commissions and investment decisions.

The difference of $€ 92.392$ billion has to do with hidden and explicit commissions ${ }^{4}$ and with erroneous investment decisions.

Table 7 is identical to Table 6 but it focuses on the last 5 years. The yield of the funds on par with the benchmark would have brought 83.693 billion Euros during the period 2002-2007, that is, an improvement of $€ 41.617$ billion over the $€ 42.076$ billion obtained. This $€ 41.617$ billion represents 99\% more than the funds actually obtained. Using the poor historical

\footnotetext{
${ }^{4}$ Explicit commissions are defined as those that the shareholders pay and that appear on the fund's contract as costs related to management, deposit, subscription and refund. Hidden commissions are those paid by the shareholders, which are derived from sales commissions arising when a manager sells securities and buys others. It is not possible to quantify the value of the latter because the great majority of funds do not release them.
} 
information offered by CNMV on fees charged by mutual funds, ${ }^{5}$ we can calculate the total of fees and charges (explicit commissions) in 2002-2007 at $€ 13.385$ billion. The remaining $€ 28.232$ billion (41.617 - 13.385) is due to hidden commissions and investment decisions.

\section{Table 7}

Period 2003-2007

\begin{tabular}{|c|c|c|c|c|c|c|c|c|c|}
\hline \multirow{2}{*}{\multicolumn{2}{|c|}{ (data in million $€$ ) }} & \multirow{2}{*}{\multicolumn{2}{|c|}{$\begin{array}{l}\text { Value of } \\
\text { Holdings } \\
\text { (million } € \text { ) }\end{array}$}} & \multirow{2}{*}{\multicolumn{2}{|c|}{$\begin{array}{c}\text { History of the } \\
\text { Period 2003-2007 } \\
\end{array}$}} & \multirow{2}{*}{\multicolumn{2}{|c|}{$\begin{array}{l}\text { If return = } \\
\text { benchmark }\end{array}$}} & \multirow{2}{*}{\multicolumn{2}{|c|}{$\begin{array}{c}\text { Difference: history vs. } \\
\text { benchmark: } \\
\text { AP hist - AP bench }\end{array}$}} \\
\hline & & & & & & & & & \\
\hline & & \multirow{2}{*}{$\begin{array}{c}\text { P2007 } \\
\text { [1] } \\
\end{array}$} & \multirow{2}{*}{$\begin{array}{c}\text { P2002 } \\
{[2]}\end{array}$} & \multirow{3}{*}{$\begin{array}{c}\text { IN NET } \\
{[3]} \\
3.451\end{array}$} & \multirow{2}{*}{$\frac{\text { AP hist }}{[4]}$} & \multirow{2}{*}{$\begin{array}{c}\text { AP } \\
\text { bench } \\
{[5]}\end{array}$} & \multirow{2}{*}{$\begin{array}{c}\text { P } 2007 \\
\text { bench } \\
{[6]} \\
\end{array}$} & million $€$ & $\%$ \\
\hline & & & & & & & & {$[7]=[4]-[5]$} & {$[8]=[7] /[4]$} \\
\hline \multirow{3}{*}{$\begin{array}{l}\text { Fixed } \\
\text { Income }\end{array}$} & Short-term & 92.254 & 80.329 & & 8.474 & 12.353 & 96.133 & -3.879 & $-46 \%$ \\
\hline & Long-term & 6.390 & 10.503 & -5.003 & 889 & 1.545 & 7.046 & -656 & $-74 \%$ \\
\hline & Mixe & 8.284 & 6.396 & 388 & 1.499 & 3. & 143 & -1.859 & $-124 \%$ \\
\hline \multirow{2}{*}{ Equity } & Mixe & 6.349 & 6.878 & -3.617 & 3.088 & 7.9 & 252 & -4.903 & $-159 \%$ \\
\hline & & 7.825 & 3.962 & -3.817 & 7.679 & 10.224 & .370 & -2.545 & $-33 \%$ \\
\hline \multirow{10}{*}{ Internat. } & Fixed Income & 903 & 1.544 & -742 & 101 & 64 & 866 & 37 & $37 \%$ \\
\hline & e Mixed & 4.733 & 7.532 & -3.444 & 645 & 322 & 4.409 & 324 & $50 \%$ \\
\hline & Equity Mixed & 2.708 & 2.410 & -575 & 873 & 1.409 & 3.243 & -536 & $-61 \%$ \\
\hline & & 7.717 & 3.230 & 1.792 & 2.695 & 6.007 & 11.029 & -3.312 & $-123 \%$ \\
\hline & Variable Europe & 5.703 & 2.261 & 1.393 & 2.049 & 2.339 & 5.992 & -290 & $-14 \%$ \\
\hline & Varia & 805 & 691 & -63 & 177 & 216 & 844 & -39 & $-22 \%$ \\
\hline & Varia & 443 & 380 & 36 & 27 & 49 & 465 & -22 & $-80 \%$ \\
\hline & Variable Emerging & 2.111 & 252 & 800 & 1.059 & 1.032 & 2.085 & 26 & $3 \%$ \\
\hline & Variable Rest & 4.462 & 3.903 & -1.262 & 1.820 & 3.858 & 6.500 & -2.038 & $-112 \%$ \\
\hline & Globals & 27.707 & 2.409 & 22.736 & 2.562 & 11.873 & 37.019 & -9.312 & $-364 \%$ \\
\hline \multirow{3}{*}{ Guaranteed } & Fixed Inco & 18.110 & 15.107 & 1.460 & 1.542 & 2.002 & 18.569 & -459 & $-30 \%$ \\
\hline & Equity & 42.192 & 23.012 & 12.288 & 6.892 & 19.050 & 54.349 & -12.158 & $-176 \%$ \\
\hline & TOTAL of FUNDS & 238.699 & 170.801 & 25.822 & 42.076 & 83.693 & 280.316 & -41.617 & $-99 \%$ \\
\hline
\end{tabular}

\section{Explicit Commissions of Mutual Funds}

Table 8 provides all the information the authors were able to obtain after consulting CNMV and INVERCO. It might be interesting to complete Table 8, but, unfortunately, we were not able to. The English TER (Total Expense Ratio) is used more and more to refer to explicit commissions and to all the charges a shareholder has to assume.

Explicit commissions are defined as those commissions that shareholders pay and that appear on the fund's contract as costs related to management, deposit, subscription and refund. Despite their names, an important part of these commissions goes to marketing and distribution expenses. A surprising fact is that in the case of many mutual funds, the sales rep's salary is higher than the manager's.

\footnotetext{
5 Table 1.7 of the IIC statistics available on the web page of CNMV offers data on the total of charges shareholders pay (management commissions, deposit commissions and operating expenses) for all the funds and starting in 2002. According to this table, the total charges that shareholders had to pay (as a percentage of average holdings of the funds) was $1.33 \%$ in 2002; $1.21 \%$ in 2003 and 2004; 1.2\% in 2005 and $1.17 \%$ in 2006.
} 


\section{Table 8}

Explicit Commissions as a \% of the Average Value of Holdings (TER) of the Mutual Funds

\begin{tabular}{|c|c|c|c|c|c|c|c|c|c|c|c|c|c|c|c|c|c|}
\hline & & 1992 & 1993 & 1994 & 1995 & 1996 & 1997 & 1998 & 1999 & 2000 & 2001 & 2002 & 2003 & 2004 & 2005 & $2006^{*}$ & 2007 \\
\hline Fixed Income & \begin{tabular}{|l|} 
Short-term \\
Long-term \\
Mixed
\end{tabular} & & & & & & & & & & & & & & & $\begin{array}{l}0.74 \% \\
1.20 \% \\
1.39 \%\end{array}$ & \begin{tabular}{|l|}
$0.52 \%$ \\
$0.86 \%$ \\
$1.08 \%$
\end{tabular} \\
\hline Equity & \begin{tabular}{|l|} 
Mixed \\
National
\end{tabular} & & & & & & & & & & & & & & & \begin{tabular}{|l|}
$1.91 \%$ \\
$1.96 \%$
\end{tabular} & \begin{tabular}{|l|}
$1.36 \%$ \\
$1.40 \%$ \\
\end{tabular} \\
\hline Internat. & $\begin{array}{l}\text { Fixed Income } \\
\text { F. Income Mixed } \\
\text { Equity Mixed } \\
\text { Variable Euro } \\
\text { Variable Europe } \\
\text { Variable USA } \\
\text { Variable Japan } \\
\text { Variable Emerging } \\
\text { Variable Rest } \\
\text { Globals }\end{array}$ & & & & & & & & & & & & & & & $\begin{array}{l}1.28 \% \\
1.42 \% \\
1.65 \% \\
2.00 \% \\
2.20 \% \\
1.75 \% \\
1.98 \% \\
2.31 \% \\
2.07 \% \\
1.37 \% \\
\end{array}$ & \begin{tabular}{|l|}
$0.76 \%$ \\
$1.00 \%$ \\
$1.21 \%$ \\
$1.45 \%$ \\
$1.55 \%$ \\
$1.16 \%$ \\
$1.51 \%$ \\
$1.92 \%$ \\
$1.50 \%$ \\
$1.00 \%$ \\
\end{tabular} \\
\hline Guaranteed. & $\begin{array}{l}\text { Fixed Income } \\
\text { Equity }\end{array}$ & & & & & & & & & & & & & & & \begin{tabular}{|l|}
$0.79 \%$ \\
$1.46 \%$
\end{tabular} & \begin{tabular}{|l|}
$0.55 \%$ \\
$1.11 \%$ \\
\end{tabular} \\
\hline & TOTAL of FUNDS & & & & & & & & & & & & & & & $1.21 \%$ & \begin{tabular}{|l|}
$0.85 \%$ \\
\end{tabular} \\
\hline
\end{tabular}

\begin{tabular}{|c|c|c|c|c|c|c|c|c|c|c|c|c|c|c|c|}
\hline table $1.7^{* *}$ & TOTAL of FUNDS & & & & $1.55 \%$ & $1.56 \%$ & & & & & \begin{tabular}{|l|}
$1.33 \%$ \\
\end{tabular} & $\mid 1.21 \%$ & $1.21 \%$ & $1.20 \%$ & $1.17 \%$ \\
\hline table $2.6^{* *}$ & TOTAL FIM & $1.80 \%$ & $1.84 \%$ & $1.79 \%$ & $1.75 \%$ & $1.66 \%$ & $1.60 \%$ & $1.68 \%$ & $1.62 \%$ & $1.54 \%$ & $1.42 \%$ & $1.31 \%$ & $1.29 \%$ & $1.27 \%$ & $1.31 \%$ \\
\hline table $3.6^{* \star}$ & TOTAL FIAMM & $1.39 \%$ & $1.39 \%$ & $1.27 \%$ & $1.36 \%$ & $1.34 \%$ & $1.24 \%$ & $1.31 \%$ & $1.17 \%$ & $1.06 \%$ & $1.04 \%$ & $1.02 \%$ & $0.99 \%$ & $0.96 \%$ & $0.45 \%$ \\
\hline table $5.7^{\star \star}$ & TOTAL guaranteed & & & & & & & & & & $1.31 \%$ & $1.33 \%$ & $1.43 \%$ & $1.39 \%$ & $1.34 \%$ \\
\hline
\end{tabular}

Source: CNMV

* According to Appendix A2.2 of the December 31, 2006 CNMV (and suppressing some of the errors it contained).

** According to IIC Statistics of CNMV corresponding to several years. 1993, 1994 y 1995: Management and deposit commissions according to Tables 6.3 and 6.9 of the annual report. 2000: total operative expenses according to Cambón (2007).

\section{Previous Studies on the Return of Mutual Funds}

The most complete study is the one realized by Palacios and Alvarez (2003) who studied the return on Spanish equity mutual funds for two periods: 21 funds from 1992 until 2001, and 55 funds from 1997 until 2001. During the 1992-2001 period, while the annual average returns of ITBM and IBEX 35 were, respectively, 16.3\% and 15.1\%, the average return on the 21 funds was of 10.7\%, and the funds with the highest return (BSN Banif ACC. Españolas and Citifondo RV) had average returns of $14.8 \%$ and 14.6\%. During the 1997-2001 period, while the annual average returns of ITBM and IBEX 35 were, respectively, 15.9\% and 12.4\%, the average return on the 55 funds was of 8.3\%, and the funds with the highest return (Chase Bolsa Plus and Bolsacaser) had average returns of 14.2\% and, respectively, 13.7\%. According to Palacios and Alvarez (2003), the average of the annual average management and deposit commissions over 1997-2001 was of $2.41 \%$.

De Lucas (1998) compared the return on 36 equity mutual funds between 1992 and 1996 to the return on IBEX 35 (without considering dividends). The comparison is incorrect as he did not include the dividends in the index, but De Lucas (1998) concluded that 11 funds had a higher return than the index. During 1992-96, when the monthly average returns on ITBM and IBEX 35 were $1.42 \%$ and 1.39\% respectively, the fund with the highest return (Fonventure) obtained an average monthly return of $1.80 \%$. Besides, four other mutual funds had a higher return than the ITBM. 
Ferruz, Marco, Sarto and Vicente (2004) compared the return on 40 stock or mixed mutual funds with the return on the overall Index of the Madrid Stock Exchange (without dividends) during the 1995-2000 period. They reached the conclusion that 16 of them had a higher return than the ITBM. However, all the 40 funds had a lower return than ITBM or Ibex 35 adjusted for dividends: during 1995-2000, while the 3-month average returns of ITBM and Ibex 35 were 6.9\% and 6.5\% respectively, the fund with the highest return (Citifondo RV) had a 3-month average return of 6.0\%.

Regarding the return on mutual funds in the United States or United Kingdom, we recommend the article by Nitzsche, Cuthbertson and 0'Sullivan (2006), which is a wonderful compilation of the articles published on the subject. Some of the conclusions are:

1. Less than $5 \%$ of stock mutual funds have a higher return than their benchmarks.

2. The mutual funds providing low returns to shareholders are persistent (they go on providing low returns).

3. The commissions, expenses and portfolio rotation have a lot of influence on the return of the funds.

4. It does not seem that "market timing" improves the return of the funds.

The authors conclude by advising investors to invest in funds with low commissions and expenses which replicate the indexes, and to avoid funds with "active management", ${ }^{6}$ especially if they have not had a flawless past.

Gil-Bazo and Ruiz-Verdú (2007) have studied funds with active management and concluded that, curiously, the lower the performance of the fund is, the higher the commission.

Kraeussl and Sandelowsky (2007) showed that the predictive capacity of the ratings of mutual funds that were released by Morningstar is similar to the predictive capacity of a random prediction.

Friesen and Sapp (2007) researched the timing ability of investors and conclude that, between 1991 and 2004, the timing decisions of investors reduced their annual return by $1.56 \%$ on average.

\section{Benchmarks Used in the Study}

Our conclusions may depend on the benchmarks that are used. Are the benchmarks used in this study reasonable?

The benchmarks we used are rather conservative. Table 9 summarizes the benchmarks that we used for the cases of stock mutual funds, short-term, fixed-income funds and long-term, fixedincome funds, and they are compared to other possible benchmarks.

\footnotetext{
${ }^{6}$ Active management occurs when fund managers frequently sell securities and buy others, so that the portfolio composition changes. With the data that most Spanish mutual funds provide, it is impossible to know if active management determined any increase in the return to shareholders, although it did generate higher returns for the stock market departments that realized the purchase and sale of securities (they charged shareholders commissions). It seems reasonable that funds inform shareholders on the amount of purchases and sales they realized and on the amount of the commissions paid (although most of the funds do not). It would also be interesting if the funds provided the exact return they would have obtained if the portfolio had stayed the same: in this manner, we could know exactly the added value (or the decrease in value) generated by active management.
} 
Spain's Stock Mutual Funds are compared to the overall index of the Madrid Stock Exchange (ITBM). After reading several affirmations from the advertisements of numerous mutual funds ${ }^{7}$ (for example, optimal selection, the best investment advisors, best management, vision over the markets, advantageous for the shareholder, efficiency, objectivity, high return, demonstrated efficiency, value generation for shareholders, increase on value added, returns impossible to reach by individual investors, global management, deep market knowledge, 30 years of experience in fund management, opportunities identification, excellent management for your investment), we could expect the managers of Spanish stock funds to do more than just reproducing a market index. As we can see form Table 9, not very imaginative strategies, such as buying at the beginning of the year, companies with higher dividend yield (Top DIV) or companies with lower market price-to-book ratios (Top Book/P), provide slightly higher returns than the ITBM. On the other hand, the fact that Ibex 35 provided a lower return than the ITBM can be easily explained by acknowledging that, as usual, smaller companies perform better, on average, than big companies. Consequently, a portfolio made up of shares from medium companies, or an investment in the IBEX 35 but with a higher weight of small companies, will have higher gains than the ITBM.

\section{Table 9}

Benchmarks Used and Potential Benchmarks

\begin{tabular}{|c|c|c|c|c|c|}
\hline & & 3 Years & 5 Years & 10 Years & 16 Years \\
\hline \multirow{12}{*}{ National Equity } & Benchmark: ITBM (overall index of the Madrid Stock Exchange) & $24.5 \%$ & $25.9 \%$ & $13.7 \%$ & $16.4 \%$ \\
\hline & IBEX 35 dividends & $22.5 \%$ & $24.1 \%$ & $10.4 \%$ & $15.1 \%$ \\
\hline & \begin{tabular}{|l} 
IBEX 35 equally weighted \\
\end{tabular} & $22.2 \%$ & $25.7 \%$ & $13.1 \%$ & $16.4 \%$ \\
\hline & Top 20 DIV weighted & $26.3 \%$ & $28.8 \%$ & $20.6 \%$ & $22.3 \%$ \\
\hline & \begin{tabular}{|l} 
Top 25 DIV weighted \\
\end{tabular} & $26.4 \%$ & $26.0 \%$ & $19.4 \%$ & $22.0 \%$ \\
\hline & Top 25 DIV equally weighted & $21.5 \%$ & $24.8 \%$ & $20.2 \%$ & $20.8 \%$ \\
\hline & Top 30 DIV weighted & $27.0 \%$ & $26.3 \%$ & $20.5 \%$ & $22.6 \%$ \\
\hline & Top 20 Book/P weighted & $40.9 \%$ & $36.5 \%$ & $30.6 \%$ & $30.8 \%$ \\
\hline & Top 20 Book/P equally weighted & $32.8 \%$ & $32.8 \%$ & $20.8 \%$ & $25.1 \%$ \\
\hline & Top 25 Book/P weighted & $31.1 \%$ & $30.5 \%$ & $28.4 \%$ & $28.2 \%$ \\
\hline & Top 25 Book/P equally weighted & $31.5 \%$ & $31.6 \%$ & $20.9 \%$ & $23.8 \%$ \\
\hline & Top 30 Book/P weighted & $29.7 \%$ & $30.4 \%$ & $26.4 \%$ & $27.5 \%$ \\
\hline \multirow{3}{*}{$\begin{array}{l}\text { Short-term, } \\
\text { fixed-income }\end{array}$} & Benchmark: AFI SPAIN GVT 1 DAY TREAS.BILL REPO & $2.9 \%$ & $2.6 \%$ & $3.2 \%$ & $5.5 \%$ \\
\hline & AFI SPAIN GVT 1 YEAR TREASURY BILL & $2.7 \%$ & $2.7 \%$ & $3.4 \%$ & $5.8 \%$ \\
\hline & \begin{tabular}{|l} 
Roll-over 12-month bill (BDE) \\
\end{tabular} & $3.2 \%$ & $2.8 \%$ & $3.3 \%$ & $5.5 \%$ \\
\hline \multirow{2}{*}{$\begin{array}{l}\text { Long-term, } \\
\text { fixed-income }\end{array}$} & Benchmark: $50 \% 3$ years y $50 \% 10$ years & $2.2 \%$ & $3.7 \%$ & $5.1 \%$ & $8.5 \%$ \\
\hline & ES BENCHMARK 10 YEAR DS GOVT. INDEX & $2.08 \%$ & $4.26 \%$ & $5.76 \%$ & $9.51 \%$ \\
\hline
\end{tabular}

Short-term, fixed-income funds (with portfolios lasting under two years) were up against the return of one-day repos, even with other more advantageous options available.

Long-term, fixed-income products are compared to a portfolio distributed evenly between 3and 10-year bonds (the comparison reveals that investing solely in the latter would be more profitable).

\footnotetext{
${ }^{7}$ See Appendix 5.
} 


\section{Fiscal Discrimination Favoring Mutual Funds and Going Against Independent Investors}

If investors used their money the same way as a mutual fund would, they would obtain a different return because:

1. They could save all explicit commissions (and almost all hidden ones).

2. They would have additional expenses for holding and buying or selling securities, and

3. They would have to pay higher taxes!

Because of a preferential fiscal treatment favoring mutual funds, the Spanish government encourages this practice. Is this logical given the facts we analyzed? It seems otherwise. Nevertheless, the Spanish government could "stimulate" investment in some of the funds but not in an indiscriminative manner.

\section{Conclusions}

When investing in a mutual fund, one expects a higher return than one could obtain by managing the money oneself. Therefore, one is prepared to pay an annual commission, sometimes higher than $2 \%$. However, the analyzed data shows that not all money managers deserve such high commissions.

In the past 10 years, mutual funds did not achieve sufficient results to cover the loss of value due to inflation.

In the past 10 and 16 years, the average return of the funds was below the return on an investment in state bonds at any term.

Despite these results, on December 31, 2007, 2,907 available funds were managing €238.699 billion for 8,264,240 shareholders.

Using rather conservative benchmarks, only 30 of the 935 10-year-history funds topped the yield benchmark. For example, from the 61 Spanish Equity Mutual Funds with more than 10 years of history, none of them outperformed the overall Index of the Madrid Stock Exchange (ITBM).

Looking back at the period 1992-2007, a yield of the funds on a par with the benchmark would have brought $€ 180$ billion instead of the $€ 80$ billion obtained. The total of fees and charges (explicit commissions), during the same period of time, reached €34 billion. The remaining €66 billion $(100-34)$ is due to hidden commissions and investment decisions.

Some of the funds -although few- did obtain important gains for their shareholders and, therefore, offered a good justification for the commissions they charged.

Lastly, the global achievement of the funds offers no justification for such favorable fiscal conditions. However, the Spanish government could encourage investment in some of the funds but not in an indiscriminative manner. 


\section{References:}

Cambón Murcia, María Isabel (2007), "Estudio sobre la evolución y los determinantes de las comisiones de gestión y depósito de los fondos de inversión," Monography no 21 of CNMV.

De Lucas, A. (1998), “Fondos de inversión en España: Análisis del Performance," Madrid Stock Exchange, February.

Fernández, P., J. M. Carabias and L. de Miguel (2007), "Rentabilidad de los Fondos de Inversión de Renta Variable Nacional en España. 1991-2006." Can be downloaded in: http://ssrn.com/abstract=985120

Ferruz, L., I., Marco, J. L. Sarto, and L. A. Vicente (2004), “La industria de los fondos de inversión en España: situación actual y evaluación de su eficiencia,” Tribuna de Economía, No. 816, pp. 163-178.

Friesen, G. C. and T. Sapp (2007), "Mutual Fund Flows and Investor Returns: An Empirical Examination of Fund Investor Timing Ability," Journal of Banking and Finance. Can be downloaded in: http://ssrn.com/abstract=957728

Gil-Bazo, J. and P. Ruiz-Verdú (2007), "Yet Another Puzzle? The Relation between Price and Performance in the Mutual Fund Industry," Universidad Carlos III de Madrid, Business Economics Working Paper No. 06-65. Can be downloaded in: http://ssrn.com/abstract=947448

Kraeussl, R. and R. M. R. Sandelowsky (2007), ”The Predictive Performance of Morningstar's Mutual Fund Ratings," Can be downloaded in: http://ssrn.com/abstract=963489

Nitzsche, D., K. Cuthbertson and N. O'Sullivan (2006), "Mutual Fund Performance." Can be downloaded in: http://ssrn.com/abstract $=955807$

Palacios, J. and L. Alvarez (2003), "Resultados de los fondos de inversión españoles: 19922001," Research Paper No, 486, IESE Business School, University of Navarra. 


\section{Appendix 1}

\section{Types of Funds and Benchmarks}

\section{NATIONAL}

1) FIAMM (Money Market Mutual Funds). They were added to the following category: Short-term, Fixed-income.

2) SHORT-TERM, FIXED-INCOME. Average duration of the portfolio: less than 2 years. Benchmark: AFI SPAIN GVT 1 DAY TREAS.BILL REPO.

3) LONG-TERM, FIXED-INCOME. Average duration of the portfolio: over 2 years. Benchmark: 50\% ES BENCHMARK 3 YEAR DS GOVT. INDEX and 50\% ES BENCHMARK 10 YEAR DS GOVT. INDEX.

4) MIXED, FIXED-INCOME. Less than 30\% of portfolio in shares. Benchmark: 75\% Long-term, Fixed-income and 25\% ITBM (overall index of the Madrid Stock Exchange).

5) MIXED EQUITIES. Between 30\% and 75\% of the portfolio in shares. A maximum of 30\% in non-Euro currencies. Benchmark: 30\% Long-term, Fixed-income and 70\% ITBM (overall index of the Madrid Stock Exchange).

6) SPANISH EQUITIES. More than 75\% of the assets in shares listed on Spanish stock markets, including Spanish securities listed on other markets. Investment in Spanish shares has to represent at least 90\% of the equity portfolio. Maximum of 30\% in non-Euro currencies. Benchmark: ITBM.

1), 2), 3) and 4): Assets in € currency (max. of 5\% in non-Euro currencies).

1), 2) and 3): They include neither equities in their cash portfolio nor derivatives based on assets that are not fixed-income. INTERNATIONAL

7) FIAMM INTERNATIONAL. They were added to the following category.

8) INTERNATIONAL FIXED INCOME. No equities in their cash portfolio nor derivatives based on assets that are not fixed-income. Benchmark: US BENCHMARK 30 YEAR DS GOVT. INDEX - TRI.

9) INTERNATIONAL MIXED FIXED INCOME. Less than 30\% of portfolio in shares. Benchmark: 75\% INTERNACIONAL FIXED INCOME and 25\% average of Equity: Euro, Europe, USA and Japan.

7), 8) and 9): Assets in non-€ currency (max. of 5\% in Euro currency).

10) INTERNATIONAL MIXED EQUITIES. Between 30\% and 75\% of the portfolio in shares. More than 30\% in non-Euro currencies. Benchmark: 30\% INTERNATIONAL FIXED INCOME and 70\% average of Equity: Euro, Europe, USA and Japan.

11) EURO EQUITIES. More than 75\% of the portfolio in shares. Spanish equities: Less than $90 \%$ of the equity portfolio. Less than 30\% in non-Euro currencies. Benchmark: 20\% Eurostoxx 50 and 80\% ITBM.

12) EUROPE INTERNATIONAL EQUITIES. More than 75\% of the portfolio in shares. European shares: More than 75\% equity portfolio. More than 30\% in non-€ currencies. Benchmark: 50\% Eurostoxx 50 and 50\% FTSE 100.

13) USA INTERNATIONAL EQUITIES. More than 75\% of the portfolio in shares. U.S. shares: more than 75\% equity portfolio. More than 30\% in non-€ currencies. Benchmark: S\&P 500.

14) JAPAN INTERNATIONAL EQUITIES. More than 75\% of the portfolio in shares. Japanese shares: more than 75\% equity portfolio. More than 30\% in non-€ currencies. Benchmark: Japan-DS.

15) EMERGING INTERNATIONAL EQUITIES. More than 75\% of the portfolio in shares. Emerging countries' shares: more than 75\% equity portfolio. More than 30\% in non-€ currencies. Benchmark: MSCI Emerging Markets Index.

16) OTHER INTERNATIONAL EQUITIES. More than 75\% of the portfolio in shares. More than 30\% in non- $€$ currencies. Different from previous categories. Benchmark: Average of [11, 12, 13, 14 and 15].

17) GLOBAL FUNDS. Funds whose investment policy is not precisely defined; they do not fit into any of the categories described. Benchmark: Average of [11, 12, 13, 14 and 15].

18) GUARANTEED FIXED INCOME. Fund with the guarantee of a third person (that can either favor the fund or the shareholders) and which can insure only a fixed return. Benchmark: Average of AFI SPAIN GVT 1 YEAR TREASURY BILL and ES BENCHMARK 3 YEAR DS GOVT. INDEX.

19) GUARANTEED EQUITY FUNDS. Fund with the guarantee of a third person (that can either favor the fund or the shareholders) and which can insure a return linked fully or partially to the performance of shares or currencies. Benchmark: 70\% AFI SPAIN GVT 1 YEAR TREASURY BILL and 30\% IBEX 35.

All funds are obliged to maintain an average monthly liquidity of 3\% of the value of their asset holdings. This $3 \%$ could slightly change the quantitative results, but not the main conclusions of this paper. 


\section{Appendix 2}

Evolution of the Value of the Asset Holdings of the Number of Funds and the Number of Shareholders per Category, 1991-2007

\section{Value of the asset holdings ( $€$ billion)}

\begin{tabular}{|c|c|c|c|c|c|c|c|c|c|c|c|c|c|c|c|c|c|c|}
\hline & & 1991 & 1992 & 1993 & 1994 & 1995 & 1996 & 1997 & 1998 & 1999 & 2000 & 2001 & 2002 & 2003 & 2004 & 2005 & 2006 & 2007 \\
\hline \multirow{3}{*}{$\begin{array}{l}\text { Fixed } \\
\text { Income }\end{array}$} & Short-term & 15.5 & 26.1 & 39.8 & 45.9 & 51.3 & 71.7 & 80.8 & 72.2 & 66.7 & 50.9 & 65.9 & 80.3 & 92.4 & 96.3 & 99.4 & 95.8 & 92,3 \\
\hline & Long-term & 4.9 & 8 & 14.1 & 13.4 & 12.5 & 18.9 & 23.9 & 27.5 & 15.4 & 11.2 & 11.7 & 10.5 & 9.9 & 9.8 & 9.9 & 7 & 6,4 \\
\hline & Mixed & 1.3 & 1.6 & 2.5 & 2.6 & 2.5 & 4.7 & 8.7 & 15.3 & 16.9 & 13.5 & 9.1 & 6.4 & 6.2 & 7.2 & 8 & 9.3 & 8,3 \\
\hline \multirow[t]{2}{*}{ Equity } & Mixed & 0.42 & 0.6 & 1.8 & 1.9 & 1.6 & 2.7 & 7 & 11.5 & 13.4 & 12.2 & 9.9 & 6.9 & 6.7 & 6.4 & 6.7 & 6.8 & 6,3 \\
\hline & National & 0.12 & 0.1 & 0.4 & 0.7 & 0.6 & 1.4 & 3.8 & 6.4 & 7.7 & 6.5 & 5.5 & 4 & 5.6 & 7.9 & 9.6 & 10.7 & 7,8 \\
\hline \multirow{10}{*}{ Internat. } & Fixed Income & 0.26 & 0.44 & 1.1 & 1.1 & 1 & 1.1 & 1.5 & 1.5 & 1.6 & 2.1 & 2.1 & 1.5 & 1.4 & 2.2 & 2.2 & 1.6 & $\overline{0,9}$ \\
\hline & F. Income Mixed & 0.47 & 0.57 & 0.9 & 0.8 & 0.8 & 1.2 & 4.2 & 10.5 & 13.4 & 11.9 & 8.9 & 7.5 & 4.8 & 4 & 4.6 & 5.3 & 4,7 \\
\hline & Equity Mixed & 0.05 & 0.06 & 0.15 & 0.28 & 0.26 & 0.7 & 2 & 3.3 & 4.5 & 5.6 & 4.5 & 2.4 & 2.5 & 3.1 & 3.5 & 3.6 & 2,7 \\
\hline & Variable Euro & 0.1 & 0.09 & 0.27 & 0.47 & 0.45 & 1 & 2.7 & 4.3 & 6 & 7.7 & 5.3 & 3.2 & 3.5 & 3.5 & 5.1 & 6.5 & 7,7 \\
\hline & Var. Europe & 0.01 & 0.02 & 0.1 & 0.1 & 0.1 & 0.1 & 0.9 & 2.9 & 3.7 & 5.3 & 3.8 & 2.3 & 2.7 & 3.1 & 5.1 & 6.7 & 5,7 \\
\hline & Variable USA & 0 & 0.01 & 0.01 & 0 & 0 & 0.01 & 0.06 & 0.14 & 0.58 & 1.12 & 1.04 & 0.69 & 1.03 & 0.88 & 1.08 & 1.31 & 0,8 \\
\hline & Variable Japan & 0 & 0 & 0.01 & 0.01 & 0.01 & 0.01 & 0.01 & 0.05 & 0.85 & 1.03 & 0.56 & 0.38 & 0.42 & 0.55 & 1.51 & 1.03 & 0,4 \\
\hline & Var. Emerging & 0.01 & 0.01 & 0.03 & 0.02 & 0.01 & 0.02 & 0.25 & 0.24 & 0.32 & 0.51 & 0.39 & 0.25 & 0.31 & 0.54 & 1.3 & 1.6 & 2,1 \\
\hline & Variable Rest & 0.01 & 0.05 & 0.13 & 0.16 & 0.12 & 0.17 & 1.1 & 2.3 & 7.7 & 9.8 & 6.5 & 3.9 & 4.2 & 4 & 4.6 & 5.4 & 4,5 \\
\hline & Globals & 0.09 & 0.1 & 0.2 & 0.3 & 0.3 & 0.3 & 0.6 & 1.1 & 2.1 & 2.3 & 3 & 2.4 & 7.1 & 16.1 & 22.9 & 30.7 & 27,7 \\
\hline \multirow[t]{2}{*}{ Guarant. } & Fixed income & & & & & 1.5 & 6.6 & 13.7 & 17.8 & 14.9 & 15 & 16.2 & 15.1 & 12.6 & 14.4 & 14.5 & 16.7 & 18,1 \\
\hline & Equity & & & & & 0.2 & 1.9 & 11.3 & 26.4 & 29.7 & 26.8 & 25.2 & 23.0 & 36.7 & 39.6 & 45.9 & 44.1 & 42,2 \\
\hline \multicolumn{2}{|c|}{ TOTAL FUNDS } & 23,2 & 37.8 & 61.6 & 67.6 & 73.3 & 112 & 162 & 204 & 206 & 183 & 180 & 171 & 198 & 220 & 246 & 254 & 238.7 \\
\hline
\end{tabular}

\begin{tabular}{|c|c|c|c|c|c|c|c|c|c|c|c|c|c|c|c|c|c|c|}
\hline \multicolumn{2}{|c|}{ Number of funds } & 1991 & 1992 & 1993 & 1994 & 1995 & 1996 & 1997 & 1998 & 1999 & 2000 & 2001 & 2002 & 2003 & 2004 & 2005 & 2006 & 2007 \\
\hline \multirow{3}{*}{$\begin{array}{l}\text { Fixed } \\
\text { income }\end{array}$} & Short-term & 137 & 181 & 218 & 234 & 249 & 298 & 352 & 376 & 400 & 398 & 371 & 372 & 411 & 398 & 357 & 373 & 386 \\
\hline & Long-term & 66 & 89 & 101 & 105 & 118 & 136 & 157 & 165 & 166 & 173 & 162 & 151 & 155 & 154 & 153 & 147 & 144 \\
\hline & Mixed & 48 & 58 & 65 & 77 & 85 & 99 & 123 & 153 & 181 & 194 & 177 & 167 & 166 & 154 & 142 & 142 & 136 \\
\hline Equity & National & 23 & 26 & 30 & 46 & 43 & 52 & 74 & 88 & 91 & 93 & 102 & 102 & 111 & 114 & 119 & 120 & 122 \\
\hline \multirow{6}{*}{ Internat. } & Fixed income & 12 & $\overline{16}$ & 23 & $\overline{26}$ & 27 & 31 & $\overline{41}$ & 45 & $\overline{51}$ & 60 & 59 & 65 & 67 & 69 & $\overline{71}$ & 72 & 65 \\
\hline & Variable Euro & 9 & 11 & 14 & 17 & 19 & 21 & 32 & 66 & 86 & 99 & 109 & 102 & 107 & 105 & 112 & 112 & 119 \\
\hline & Var. Europe & 4 & 4 & 4 & 6 & 7 & 7 & 19 & 29 & 36 & 50 & 65 & 61 & 63 & 63 & 67 & 68 & 71 \\
\hline & Variable USA & 1 & 1 & 1 & 1 & 1 & 2 & 6 & 9 & 23 & 37 & 48 & 50 & 49 & 44 & 41 & 41 & 43 \\
\hline & Variable Japan & 1 & 1 & 2 & 2 & 2 & 2 & 2 & 7 & 16 & 29 & 29 & 28 & 27 & 23 & 24 & 26 & 25 \\
\hline & Var. Emerging & 2 & 2 & 2 & 2 & 3 & 4 & 11 & 11 & 17 & 38 & 39 & 35 & 34 & 41 & 43 & 51 & 59 \\
\hline \multicolumn{2}{|c|}{ TOTAL FUNDS } & 374 & 480 & 579 & 663 & 752 & 959 & 1458 & 1867 & 2154 & 2426 & 2540 & 2487 & 2623 & 2654 & 2616 & 2779 & 2.907 \\
\hline
\end{tabular}

\begin{tabular}{|c|c|c|c|c|c|c|c|c|c|c|c|c|c|c|c|c|c|c|}
\hline \multicolumn{2}{|c|}{ Shareholders (thousand) } & 1991 & 1992 & 1993 & 1994 & 1995 & 1996 & 1997 & 1998 & 1999 & 2000 & 2001 & 2002 & 2003 & 2004 & 2005 & 2006 & 2007 \\
\hline \multirow{3}{*}{$\begin{array}{l}\text { Fixed } \\
\text { Income }\end{array}$} & Short-term & 482 & 777 & 1,588 & 1,782 & 2,017 & 2,739 & 3,082 & 2,840 & 2,493 & 1,908 & 2,183 & 2,339 & 2,585 & 2,577 & 2,656 & 2,605 & 2.450 \\
\hline & Long-term & 360 & 625 & 536 & 515 & 408 & 596 & 726 & 830 & 546 & 325 & 318 & 274 & 284 & 289 & 310 & 331 & 354 \\
\hline & Mixed & 136 & 93 & 94 & 104 & 92 & 177 & 354 & 614 & 712 & 567 & 384 & 290 & 292 & 291 & 313 & 314 & 297 \\
\hline \multirow[t]{2}{*}{ Equity } & Mixed & 50 & 41 & 87 & 110 & 82 & 113 & 302 & 503 & 565 & 558 & 463 & 384 & 361 & 327 & 291 & 257 & 260 \\
\hline & National & 20 & 27 & 31 & 49 & 41 & 63 & 173 & 286 & 298 & 292 & 262 & 256 & 279 & 356 & 371 & 348 & 309 \\
\hline \multirow{10}{*}{ Internat. } & Fixed Income & 39 & 44 & 46 & 44 & 34 & 32 & 53 & 59 & 73 & 71 & $\overline{70}$ & 58 & 70 & 104 & 106 & 114 & $\overline{72}$ \\
\hline & F. Income Mixed & 43 & 51 & 108 & 99 & 84 & 95 & 195 & 398 & 490 & 432 & 395 & 338 & 210 & 182 & 195 & 216 & 214 \\
\hline & Equity Mixed & 3 & 4 & 10 & 17 & 14 & 25 & 67 & 126 & 158 & 249 & 233 & 201 & 176 & 143 & 131 & 110 & 91 \\
\hline & Variable Euro & 2 & 3 & 23 & 40 & 33 & 49 & 124 & 187 & 210 & 313 & 292 & 252 & 248 & 223 & 258 & 290 & 300 \\
\hline & Var. Europe & 2 & 2 & 4 & 9 & 7 & 10 & 49 & 164 & 124 & 229 & 191 & 188 & 180 & 195 & 244 & 260 & 259 \\
\hline & Variable USA & 0 & 0 & 0 & 0 & 0 & 0 & 2 & 4 & 27 & 43 & 40 & 41 & 44 & 72 & 81 & 131 & 50 \\
\hline & Variable Japan & 0 & 0 & 1 & 1 & 1 & 1 & 1 & 3 & 52 & 91 & 74 & 68 & 61 & 67 & 86 & 85 & 52 \\
\hline & Var. Emerging & 1 & 1 & 2 & 2 & 2 & 2 & 19 & 24 & 24 & 43 & 37 & 34 & 32 & 46 & 78 & 112 & 157 \\
\hline & Variable Rest & 2 & 3 & 13 & 17 & 12 & 13 & 54 & 129 & 363 & 732 & 660 & 626 & 577 & 509 & 425 & 397 & 303 \\
\hline & Globals & 5 & 5 & 5 & 7 & 5 & 6 & 15 & 18 & 53 & 79 & 92 & 92 & 183 & 511 & 564 & 880 & 772 \\
\hline \multirow[t]{2}{*}{ Guarant. } & Fixed Income & & & & & 105 & 291 & 538 & 660 & 566 & 548 & 597 & 550 & 430 & 494 & 544 & 584 & 578 \\
\hline & Equity & & & & & 9 & 81 & 492 & 1,145 & 1,268 & 1,180 & 1,158 & 1,134 & 1,619 & 1,656 & 1,903 & 1,785 & 1.747 \\
\hline \multicolumn{2}{|c|}{ TOTAL FUNDS } & 1.145 & 1,677 & 2,548 & 2,794 & 2,944 & 4,290 & 6,243 & 7,984 & 8,012 & 7,655 & 7,449 & 7,127 & 7,632 & 8,041 & 8,555 & 8,820 & 8,264 \\
\hline
\end{tabular}


Average value of holdings per fund (million $€$ )

\begin{tabular}{|c|c|c|c|c|c|c|c|c|c|c|c|c|c|c|c|c|c|c|}
\hline & & 1991 & 1992 & 1993 & 1994 & 1995 & 1996 & 1997 & 1998 & 1999 & 2000 & 2001 & 2002 & 2003 & 2004 & 2005 & 2006 & 2007 \\
\hline \multirow{3}{*}{$\begin{array}{l}\text { Fixed } \\
\text { Income }\end{array}$} & Short-term & 113 & 144 & 183 & 196 & 206 & 240 & 230 & 192 & 167 & 128 & 178 & 216 & 225 & 242 & 279 & 257 & 239 \\
\hline & Long-term & 74 & 90 & 140 & 127 & 106 & 139 & 152 & 167 & 93 & 64 & 72 & 70 & 64 & 63 & 65 & 48 & 44 \\
\hline & Mixed & 27 & 28 & 39 & 33 & 29 & 47 & 71 & 100 & 93 & 70 & 51 & 38 & 37 & 47 & 56 & 65 & 61 \\
\hline \multirow[t]{2}{*}{ Equity } & Mixed & 10 & 12 & 29 & 25 & 20 & 30 & 53 & 70 & 73 & 62 & 52 & 36 & 37 & 40 & 45 & 47 & 44 \\
\hline & National & 5 & 5 & 14 & 14 & 15 & 26 & 51 & 73 & 84 & 70 & 54 & 39 & 50 & 69 & 81 & 89 & 64 \\
\hline \multirow{10}{*}{ Internat. } & F. Income & 21 & 27 & 49 & 42 & 37 & 35 & 36 & 34 & 32 & 35 & 36 & 24 & 20 & 32 & 31 & 23 & 14 \\
\hline & F. Inc. Mixed & 43 & 31 & 42 & 31 & 27 & 37 & 109 & 198 & 179 & 142 & 107 & 84 & 49 & 49 & 63 & 71 & 62 \\
\hline & Equity Mixed & 11 & 10 & 11 & 14 & 12 & 23 & 44 & 56 & 59 & 64 & 44 & 23 & 23 & 37 & 44 & 45 & 34 \\
\hline & Var. Euro & 11 & 8 & 19 & 27 & 23 & 46 & 85 & 65 & 70 & 77 & 49 & 32 & 32 & 33 & 46 & 58 & 65 \\
\hline & Var. Europe & 4 & 4 & 13 & 15 & 11 & 20 & 46 & 100 & 103 & 105 & 58 & 37 & 43 & 50 & 76 & 98 & 80 \\
\hline & Var. USA & 5 & 8 & 6 & 4 & 3 & 6 & 10 & 15 & 25 & 30 & 22 & 14 & 21 & 20 & 26 & 32 & 19 \\
\hline & Var. Japan & 1 & 1 & 4 & 4 & 4 & 3 & 3 & 8 & 53 & 36 & 19 & 14 & 16 & 24 & 63 & 40 & 18 \\
\hline & Var.Emerging & 3 & 5 & 15 & 10 & 5 & 5 & 23 & 22 & 19 & 13 & 10 & 7 & 9 & 13 & 30 & 32 & 36 \\
\hline & Var. Rest & 3 & 7 & 16 & 16 & 12 & 11 & 21 & 26 & 55 & 47 & 29 & 17 & 20 & 23 & 28 & 33 & 28 \\
\hline & Globals & 11 & 13 & 16 & 19 & 17 & 16 & 15 & 20 & 25 & 22 & 18 & 18 & 39 & 62 & 78 & 88 & 66 \\
\hline \multirow[t]{2}{*}{ Guarant. } & Fixed Income & & & & & 57 & 81 & 82 & 95 & 81 & 77 & 77 & 72 & 59 & 64 & 63 & 61 & 69 \\
\hline & Equity & & & & & 18 & 53 & 67 & 87 & 85 & 70 & 61 & 58 & 83 & 79 & 92 & 82 & 71 \\
\hline \multicolumn{2}{|c|}{ TOTAL FUNDS } & 62 & 79 & 106 & 102 & 97 & 117 & 111 & 109 & 95 & 76 & 71 & 69 & 75 & 83 & 94 & 92 & 82 \\
\hline
\end{tabular}

Average value of holdings per shareholder (thousand €)

\begin{tabular}{|c|c|c|c|c|c|c|c|c|c|c|c|c|c|c|c|c|c|c|}
\hline & & 1991 & 1992 & 1993 & 1994 & 1995 & 1996 & 1997 & 1998 & 1999 & 2000 & 2001 & 2002 & 2003 & 2004 & 2005 & 2006 & 2007 \\
\hline \multirow{3}{*}{$\begin{array}{l}\text { Fixed } \\
\text { Income }\end{array}$} & Short-term & 32 & 34 & 25 & 26 & 25 & 26 & 26 & 25 & 27 & 27 & 30 & 34 & 36 & 37 & 37 & 37 & 38 \\
\hline & Long-term & 13 & 13 & 26 & 26 & 31 & 32 & 33 & 33 & 28 & 34 & 37 & 38 & 35 & 34 & 32 & 21 & 18 \\
\hline & Mixed & 10 & 17 & 27 & 25 & 27 & 27 & 25 & 25 & 24 & 24 & 24 & 22 & 21 & 25 & 26 & 30 & 28 \\
\hline \multirow[t]{2}{*}{ Equity } & Mixed & 8 & 14 & 21 & 17 & 20 & 24 & 23 & 23 & 24 & 22 & 21 & 18 & 19 & 20 & 23 & 27 & 24 \\
\hline & National & 6 & 5 & 13 & 13 & 16 & 22 & 22 & 22 & 26 & 22 & 21 & 15 & 20 & 22 & 26 & 31 & 25 \\
\hline \multirow{10}{*}{ Internat. } & Fixed Income & 7 & 10 & 24 & 25 & 29 & 34 & 28 & 26 & 22 & 29 & 31 & 27 & 19 & 21 & 20 & 14 & $\overline{13}$ \\
\hline & F. Income Mixed & 11 & 11 & 8 & 8 & 9 & 13 & 21 & 26 & 27 & 28 & 23 & 22 & 23 & 22 & 23 & 25 & 22 \\
\hline & Equity Mixed & 20 & 14 & 15 & 17 & 19 & 28 & 29 & 27 & 28 & 23 & 19 & 12 & 14 & 22 & 27 & 33 & 30 \\
\hline & Variable Euro & 41 & 28 & 11 & 12 & 14 & 19 & 22 & 23 & 29 & 25 & 18 & 13 & 14 & 16 & 20 & 23 & 26 \\
\hline & Var. Europe & 9 & 7 & 12 & 10 & 11 & 15 & 18 & 18 & 30 & 23 & 20 & 12 & 15 & 16 & 21 & 26 & 22 \\
\hline & Variable USA & 27 & 39 & 30 & 33 & 57 & 26 & 40 & 38 & 22 & 26 & 26 & 17 & 24 & 12 & 13 & 10 & 16 \\
\hline & Variable Japan & 12 & 12 & 14 & 12 & 11 & 12 & 9 & 19 & 16 & 11 & 8 & 6 & 7 & 8 & 18 & 12 & 9 \\
\hline & Var. Emerging & 7 & 7 & 14 & 8 & 7 & 10 & 13 & 10 & 13 & 12 & 10 & 7 & 9 & 12 & 16 & 14 & 13 \\
\hline & Variable Rest & 5 & 16 & 10 & 10 & 10 & 13 & 19 & 18 & 21 & 13 & 10 & 6 & 7 & 8 & 11 & 14 & 15 \\
\hline & Globals & 19 & 25 & 42 & 41 & 51 & 52 & 40 & 63 & 39 & 29 & 33 & 26 & 39 & 31 & 41 & 35 & 36 \\
\hline \multirow[t]{2}{*}{ Guarant. } & Fixed Income & & & & & 15 & 23 & 25 & 27 & 26 & 27 & 27 & 27 & 29 & 29 & 27 & 29 & 31 \\
\hline & Equity & & & & & 24 & 23 & 23 & 23 & 23 & 23 & 22 & 20 & 23 & 24 & 24 & 25 & 24 \\
\hline \multicolumn{2}{|c|}{ TOTAL FUNDS } & 20 & 23 & 24 & 24 & 25 & 26 & 26 & 26 & 26 & 24 & 24 & 24 & 26 & 27 & 29 & 29 & 29 \\
\hline
\end{tabular}

Source: Inverco 


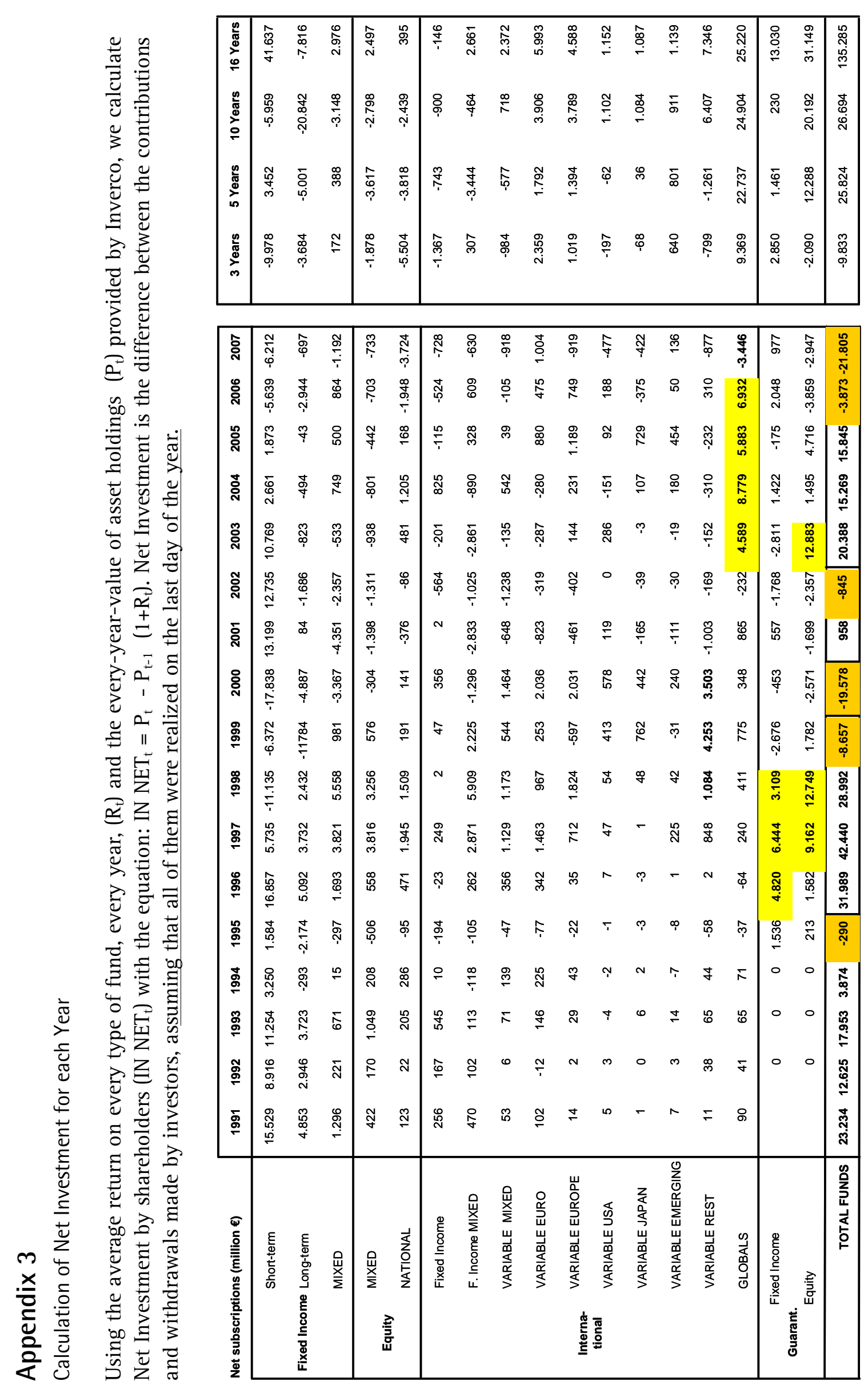

IESE Business School-University of Navarra - 19 


\section{Appendix 4}

Fees and Expenses of Mutual Funds

Management commission: Commission paid out of fund assets to the fund's investment adviser. It can be established as a function of the value of the assets, of the returns or of both variables (there may be differences in the commissions according to the duration of the investment, etc.). There are maximum limits: $2.25 \%$ if applied to the value of the holdings, $18 \%$ if it depends on the return, and, if both variables are used, it can not be higher than $1.35 \%$ of the value of the holdings and $9 \%$ of the returns.

Deposit commission: A fee imposed on fund assets, in connection with the maintenance of the securities. Generally, this commission is not higher than an annual $2 \%$ of the value of the assets.

Subscription commission: Another type of fee that funds charge their shareholders as a percentage of the invested capital when subscribing for shares of the fund. It cannot be higher than 5\% of the value of the subscribed shares. There may be differences depending on the duration of the investment, etc.

Refund Commission: A type of fee that funds impose on shareholders as a percentage of the capital that was refunded. It cannot be higher than $5 \%$ of the liquidity value of refunded shares. The conditions and amount of this type of load will depend on how long the investor holds his or her shares.

Discount favoring the fund: Sometimes the fund's investment adviser passes part of the subscription and refund commissions charged to the fund; it is called discount commission favoring the fund and it benefits all the fund's shareholders.

Total Fund Operating Expenses (TER, Total Expense Ratio): It represents a percentage of the total of a fund operating expenses from the beginning of the calendar year until the present date. Total expenses include management and deposit commissions, external services and other operating expenses. The less the percentage is, the higher the profit for the shareholders. 


\section{Appendix 5}

Advertising Fragments Used by Some Mutual Funds (translated)

Asset management should be left to an expert. We have been considered one of the best managers of equity funds for years. Therefore, you can expect a high return for your money.

Our funds offer: 1. Optimal selection. We select the best specialists for all types of assets in order to ensure access to the best investment advisers. 2. Active management. Using this analysis and our vision of the markets, our team actively manages the portfolio. Dynamism and reduced cost are an important advantage for the shareholder in terms of efficiency.

Our investment style has proven its efficiency. Active management can generate value for the shareholders.

Our objective is to efficiently combine valued added management with personalized management. We propose the following management style: active management whose goal is to protect the value of asset holdings and strive for long-term value.

Mutual funds allow every individual access to the financial markets in an easy manner to allow them to obtain returns that would be out of reach for independent investors.

We offer the possibility of global management.

Our resources in analysis and asset management provide us with a deep knowledge of the market.

We offer more than 30 years of management experience in all types of assets in international markets, with team focused on serving clients.

Our analysts can identify opportunities that the market offers.

When you invest in our funds, you leave your money in the hands of managers capable of offering an excellent management of your investment.

Start saving now without effort and you will see how your money grows!

With our funds, you can expect high-potential returns and benefit from the lowest commissions on the market. To be more precise, you could save between 51\% and 65\% from the maximum legally allowed.

There is one certainty: the lower the commissions you pay, the more money in your pocket.

Our fund is managed by a team of professionals characterized by talent and experience.

Our funds allow you to make money easily, without having to lift a finger.

If you still have a few years left until retirement, we can provide you with high-return funds which would help you earn the money you need to add to your pension.

We offer the most profitable funds so that you can take advantage of your savings.

We capitalize on the experience and advantages acquired over time.

Our funds provide high returns for your savings with the best fiscal treatment. 


\section{Appendix 6}

Press Clippings on the Evolution of Mutual Funds (translated)

In 2007:

The weighted average return in the past 12 months was $2.40 \%$. The balance realized the last day of the year reflects the reality of the mutual funds as it is: moderate returns with a downward tendency caused by the second-semester crisis of subprime mortgages. Except for Emerging Equity, the other categories which made a profit were very moderate. Despite investment risks, the returns most of them obtained were lower than on a simple and safe term deposit...We hope 2008 will be more profitable.

\section{In 2006:}

In 2006 more than half of the mutual funds obtained a higher return than the market. Fiftyfour percent of the mutual funds closed last year with real gains. Of the 2,585 funds available at the end of 2005 which remained on the market during 2006, 1,395 finished the year with a positive return, as their gains were higher than inflation.

The product with the highest return was the global fund CS Euroceánico Global (Credit Suisse) which gained 158.3\%, followed by the Euro zone stock fund BK Pequeñas Compañias, with $60.8 \%$. The first fund on the negative side was Córdoba Rural Rentabilidad Absoluta, with losses of 36.07\%. Morgan Stanley Euro/Dolár 2005, a guaranteed fund, lost 17.2\%, where as Morgan Stanley Dinerario lost 16.9\% and Gaesco Japan had losses of 16.6\%.

\section{In 2005:}

In 2005, mutual funds closed with a gain of 4.75\%, a number that outperformed the inflation for the period - 3.8\% - also the highest return of the past 6 years, according to Inverco. For the third consecutive year, all the families closed with positive values, although the ones with best results were those investing in emerging markets stock markets (54\%). The next products with the highest returns were those investing in Japanese equity, given that between January and December 2005 they gained 39.8\%.

On the other hand, money market funds (FIAMM) had the lowest gains in 2005, 1.17\%, followed by short-term, fixed-income funds with 1.53\%, and guaranteed equity funds with 1.87\%.

Although equity funds had the highest returns, conservative products became the first money receptors, as $€ 4.960$ billion were invested in short-term, fixed-income funds, €3.738 billion in global funds and $€ 2.984$ billion in guaranteed equity funds.

\section{In 1997:}

In 1997, mutual funds were back on top of the list of products with highest gains. Their average profit was a lot higher than the return on bank deposits (around 5\%). Direct equity investment itself generated a higher return (Madrid Stock Index gained 40\% in 1997). However, equity purchase is, according to some experts, a riskier investment than buying shares in a mutual fund. Companies of mutual investment are managed by investment advisors who follow the markets on a daily basis and decide, according to circumstances, what and when to buy or sell.

Mutual funds invest the money in a lot of securities at the same time, offering small investors the opportunity to diversify. Moreover, fund managers consider 1998 stock market as being rather difficult. 


\section{Appendix 7}

Comments by Readers on Previous Versions of this Paper (some translated)

I sincerely thought that good managers would outperform the index by 3 or $4 \%$ at least. If fund managers are incapable of generating higher returns than the indexes, then which is their role? Isn't it better to invest in shares directly?

I worked for four years in a securities agency as an agent and I said to myself never to invest in mutual funds or to recommend it to anybody. As an agent I used to earn commissions, while my clients lost money without explanation...

Any manager who could guarantee a better result than the index would now have been a long time in the Bahamas.

The Bestinver case deserves homage... and an analysis in order to learn.

I always had it clear: the winners are the funds and their investment advisers. It is better to buy shares directly rather than invest in a fund.

Funds with few transactions and investments in long-term (10 years) large companies' securities do have better results than the IBEX.

It is illogical that the AEAT maintain such favorable conditions for mutual funds given the complete uselessness of many fund managers. There is now the possibility of customers changing fund without being penalized but the independent investor still has no access to the favorable fiscal treatment that mutual funds enjoy.

If markets are efficient, the average expected return on a fund (given the volatility of the index) is the return on the index minus all expenses charged by the fund. The problem is which and how many should the costs of a fund be and deciding whether such costs do compensate for any other alternative to get to the index. Costs for an investor: fiscal, transaction costs, management, operating and distribution. Discussing this problem is similar to discussing whether tomatoes in the supermarket should have the same price as the one the farmer receives.

The fund's investment managers pass on to the bank distribution networks between the $80 \%$ and $95 \%$ of the commissions they charge.

The professional management of a fund should provide the shareholder with the following elements of value (that no other investments provide):

- A return that follows the index (no higher than that, as the theory of market efficiency postulates that statistically it is impossible to reach or promise) before the costs.

- Reasonable costs based on elements like: daily liquidity, diversification, operating control of the portfolio with its suitable reporting, implicit fiscal charges, an excellent network assessment to recommend which the most appropriate asset allocation, depending on the unique circumstances of each investor, security.

It seems that almost no fund investment adviser deserves his or her fees.

I only have two ideas: 1 . Investment in the stock market is better than in a mutual fund. 2. Bestinver seems to be the only serious fund manager.

All this reminds me of the example of the monkey that obtained a higher return with its fund than the experts.

The "invention" of the benchmark was the way out for mediocre fund managers to justify themselves with an index. But I want to underline the role of a good manager. It is fundamental to trust in the professional profile of the person more than in the name of the fund or entity for which he or she is working.

Thank you so much, but l'm afraid that if you go on publishing such articles we are not going to be able to sell a fund for many years...

Few fund managers were able to outperform the indexes during large periods of time. The most famous one is Warren Buffet (Berkshire Hathaway). They usually buy undervalued shares and wait for the necessary period of time until the market recognizes their value. If, once they buy the shares, the value goes down they feel even happier as they then have the possibility of buying more at a lower price.

Does all this have anything to do with the Theory of Random Walk by Burton Malkiel?

The numbers speak for themselves while the fund managers are the only ones that obtained a return, outrageous, I would say. Then, why does the investor still invest in mutual funds? I personally think that a great majority of them are assessed by a fiscal assessor.

Banks are the main institutions that acknowledge to common citizens that the stock market offers high returns, but that their investment has to be managed by professionals. As they start losing, what makes clients go on is the promise of recuperation. The professionals always receive their commissions whether the fund won or lost.

Lucky me that in the past 5 years I kept my mother's money in non-managed index funds with low commissions!

An investor buying several shares randomly would have a higher return than the funds.

It would be interesting to compare the gains of the fund managers with that of their clients!

I personally got a return of $0.068 \%$ in three years in a guaranteed fund from XXX. Maybe sometimes the return on my savings will be enough to cover the loss of value due to inflation - this is my only target as a professional living off his insomnia and seeing money just as raw material.

The amount of explicit commissions was shocking and revealing... and the hidden commissions even more so.

It is strange that articles stating the contrary are sold on a daily basis. Unfortunately, it is a reality that does not affect solely the financial sector.

If you could only see how tired we are of keep explaining to our customers the matter of timing and the unfortunate fundpicking but they do not understand it. We offer numerous empirical proves but it does not work.

It is incredible how much we pay on management commissions when a passive management fund would provide a higher return in the long run (for a lower commission and a better performance). 
I always kept my money in savings accounts: with small returns, but almost always inflation $+1 \%$, immediate availability, zero commissions and short-term. At the moment I enjoy the market circumstances, higher than $4 \%$, always one-year Euribor minus 10-20 basic points.

Reading this document, I recall Nassim Taleb and his book "Fooled by the Randomness" or his more recent "Black Swam". There is so much money unjustifiably spent on professional management of the portfolio without real results to explain it.

Something or somebody keeps changing the results leaving fund advisers used to offering explanations for their bad management, with no argument. I sincerely do not believe in "wrong decisions" and in the possibility of improving them, as they always favor a specific person and go against the shareholder.

I understood long ago the "mechanism" of mutual funds and gave up investing in them. Now I only invest in pension funds, conscious of giving part of my fiscal profits to the management agency.

I am a trader and I also manage the portfolio of the bank and...your daughter could definitely do it better!

The biggest problem is the lack of passive retail funds in Spain (with a vocation of "buy and hold") with passive-fund commissions (clearly under $0.5 \%$ ). This is the main difference between the Spanish fund industry and the typically US/UK one, placing the Spanish industry in a worse statistical position.

Now that we have the ETFs, it's worth questioning the subscription fees charged by the great institutions.

I completely agree: stock funds have a lower return than market indexes, even if we look at the most conservative ones.

Lately, journalists seem to be on the side of fund managers in economic pages, which start to stink.

The funds trade a high volume of assets which allows them discounts in the sale and purchase commissions, that otherwise would be inaccessible to an independent investor.

The biggest problem with the funds is that they use politics ("stop loss", etc.) that require a great deal of transactions (which may generate more hidden commissions). This technique significantly decreases the return of a long-term investment.

An investor that was pressured in the 90 s to sell his/her shares and to invest in a fund (for the fiscal benefits) and did not do so... is now laughing at the adviser who recommended it.

I invest in mutual funds that replicate market indexes because they have lower commissions and because I can have my own opinion on what an index is going to do.

There are many fund advisers who do not obtain any increase in value.

There are many different fund managers: some are good and many are mediocre or bad.

The Spanish market is very vulnerable to an US/UK invasion with a strategy of distribution acquisitions (or agreement with the large companies) and a lot of marketing.

The most important thing in Spain is to channel family savings into investment. The percentage of investment in equity in Spain is a lot lower than the European or US/UK average.

I think that most investors invest in mutual funds because they look for a higher return than inflation and bonds...and they don't really care about outperforming the benchmark. As your analysis well shows, an independent investor could have outperformed the return on the funds...but maybe the investors think they could use this loss of time, effort and dedication in a better way ... work, holidays, books, sports, rest, etc...?

I met so many clients who were upset because of a negative return on the fund or because of an excessively low return...for not being able to get a bigger portion of a good start.

Fiscal treatment should be the same for direct investment and for investment through mutual funds. The only difference is the degree of complexity of the fund management but the investment philosophy is the same.

I am a small investor in Vanguard funds (indexed, minimum commissions and which do not require any concern regarding the quality of the manager or the small print) and in Bestinver. This saves me from feeling like a fool when I read the front pages and the rankings of economic journals.

My first savings went to mutual funds. I got a low return in one of them and lost in the other one. First disappointment - I thought foreigners could do it better. I was recommended some experts (Growth portfolio) and I still have losses after 5 years. Of course, they charged commissions: in the first year, they would take $4 \%$, in the second, $3 \%$... I no longer buy funds. My recommendation: buy in the stock market using your own criteria and do the fund yourself. You will make more money, have fun and it will be only your own fault if you go bankrupt.

Almost all funds should return commissions: I do not need anybody else in order to make less money than with a fund indexed to the Madrid Stock Exchange.

The most important matter is to have a good investment adviser who could make you enter a fund at the right moment, leave it when it is no longer appropriate and enter the same fund or another one when things are back on track.

If one buys a fund and remains inactive over the years, then the return will not be optimized.

If we calculated the average of the funds and take into consideration the few good ones and the large group of mediocre and bad then the return we would get would be the one from your paper.

I am going to buy Treasury bills, now!

The truth is that I do not really know whether it is better to have a lot of money invested in funds at such low returns, or, as in my case, to have the right amount to live well, without expecting high returns but, at least, not having to feel "cheated"...

Mutual funds are just an old wives' tale...the only people who make money with them are the banks.

This shows the persistency of alpha is a tall story. That is why fund selection (or management, actually) is so difficult.

Hedge funds are going to be the next fraud, as they are abusive in commissions. And the worst thing is that the fiscal regime is very favorable for the funds; one can move from a fund to another without paying taxes but one cannot sell lberdrola and buy Telefónica in the same way. With money and fixed-income funds the difference is based on commissions. Cheap funds do it well, but there are others which are very, very expensive.

Our organization does numerous analyses that, unfortunately, reach the same conclusion. 